\title{
Vervangingsvraag naar beroep en stromen op de arbeidsmarkt
}

Citation for published version (APA):

Cörvers, F., Dijksman, S., Kriechel, B., \& Montizaan, R. M. (2010). Vervangingsvraag naar beroep en stromen op de arbeidsmarkt. ROA. ROA Technical Reports No. 3 https://doi.org/10.26481/umarot.2010003

Document status and date:

Published: 01/01/2010

DOI:

10.26481/umarot.2010003

Document Version:

Publisher's PDF, also known as Version of record

\section{Please check the document version of this publication:}

- A submitted manuscript is the version of the article upon submission and before peer-review. There can be important differences between the submitted version and the official published version of record.

People interested in the research are advised to contact the author for the final version of the publication, or visit the DOI to the publisher's website.

- The final author version and the galley proof are versions of the publication after peer review.

- The final published version features the final layout of the paper including the volume, issue and page numbers.

Link to publication

\footnotetext{
General rights rights.

- You may freely distribute the URL identifying the publication in the public portal. please follow below link for the End User Agreement:

www.umlib.nl/taverne-license

Take down policy

If you believe that this document breaches copyright please contact us at:

repository@maastrichtuniversity.nl

providing details and we will investigate your claim.
}

Copyright and moral rights for the publications made accessible in the public portal are retained by the authors and/or other copyright owners and it is a condition of accessing publications that users recognise and abide by the legal requirements associated with these

- Users may download and print one copy of any publication from the public portal for the purpose of private study or research.

- You may not further distribute the material or use it for any profit-making activity or commercial gain

If the publication is distributed under the terms of Article $25 \mathrm{fa}$ of the Dutch Copyright Act, indicated by the "Taverne" license above, 


\section{Vervangingsvraag naar beroep en stromen op de arbeidsmarkt}

Frank Cörvers

Sander Dijksman

Ben Kriechel

Raymond Montizaan

\section{ROA Technical Report}

ROA-TR-2010/3

Research Centre for Education and the Labour Market Maastricht University

P.O. Box 616, 6200 MD Maastricht, The Netherlands

$\mathrm{T}+31433883647 \mathrm{~F}+31433884914$

secretary-roa-sbe@maastrichtuniversity.nl www.roa.nl 


\title{
Vervangingsvraag naar beroep en stromen op de arbeidsmarkt
}

\author{
Frank Cörvers \\ Sander Dijksman \\ Ben Kriechel \\ Raymond Montizaan
}

ROA-TR-2010/3

Maart 2010

Research Centre for Education and the Labour Market Maastricht University

P.O. Box 616, 6200 MD Maastricht, The Netherlands

$\mathrm{T}+31433883647 \mathrm{~F}+31433884914$

secretary-roa-sbe@maastrichtuniversity.nl www.roa.nl 


\section{Voorwoord}

Deze studie heeft plaatsgevonden in het kader van het Project Onderwijs-Arbeidsmarkt (POA). Dit project wordt gefinancierd door het Ministerie van Onderwijs, Cultuur en Wetenschap (OCW), het Uitvoeringsinstituut Werknemersverzekeringen (UWV), het UWV Werkbedrijf, het Ministerie van Landbouw, Natuur en Voedselkwaliteit (LNV), de samenwerkende kenniscentra voor beroepsonderwijs en bedrijfsleven COLO, Randstad Nederland en de Raad voor Werk en Inkomen (RWI). 


\section{Inleiding}

Het Researchcentrum voor Onderwijs en Arbeidsmarkt (ROA) maakt in het kader van het Arbeidsmarktinformatiesysteem (AIS) iedere twee jaar middellangetermijnprognoses naar opleiding en beroep. De laatste prognoses zijn terug te vinden in De arbeidsmarkt naar opleiding en beroep tot 2014 (ROA, 2009) en het bijbehorende Arbeidsmarktinformatiesysteem (AIS). De prognosemethodiek die wordt gehanteerd is uitgebreid besproken in werkdocumenten. De werkdocumenten laten zien dat het ROA over de jaren heen heeft geprobeerd om de prognosemethodiek te verfijnen en indien mogelijk het prognosemodel te verbeteren om de bruikbaarheid van de resultaten te verhogen. In dit werkdocument wordt verkend in hoeverre het mogelijk is om een specifiek onderdeel van het prognosemodel, namelijk de vervangingsvraagmethodiek, verder te verbeteren.

De vervangingsvraag is de vraag die ontstaat vanwege (vervroegde) pensionering, arbeidsongeschiktheid, tijdelijke terugtrekking van de arbeidsmarkt en baan-baanmobiliteit voor zover deze plaatsvindt tussen verschillende beroepsgroepen. De uitbreidingsvraag en de vervangingsvraag leveren samen het verwachte aantal baanopeningen per beroepsgroep op. Verondersteld is dat deze baanopeningen de voor studie- en beroepskeuzedoeleinden relevante grootheid is. De vervangingsvraag naar opleiding wordt apart berekend, omdat deze niet uit de vervangingsvraag naar beroep kan worden afgeleid. De vervangingsvraag naar beroep wijkt af van de vervangingsvraag naar opleiding omdat baan-baanmobiliteit tussen beroepsgroepen op zichzelf niet leidt tot vervangingsvraag naar opleiding. Daarentegen leidt het behalen van een diploma van werkenden in een andere opleidingsrichting of op een hogere opleidingsniveau wel tot vervangingsvraag naar opleiding, maar niet per se tot vervangingsvraag naar beroep. Tezamen vormen de vervangingsvraag en de uitbreidingsvraag de totale vraag naar nieuwkomers met de desbetreffende beroepsuitoefening of opleidingsachtergrond. Deze totale vraag geeft het aantal baanopeningen weer dat beschikbaar komt voor schoolverlaters. Door de baanopeningen te confronteren met de instroom van schoolverlaters op de arbeidsmarkt, wordt een indicatie verkregen van de te verwachten discrepanties op de arbeidsmarkt, gedifferentieerd naar opleiding en beroep.

In het verleden waren paneldata over de beroepenmobiliteit niet beschikbaar, waardoor voor het bepalen van de vervangingsvraag een model is ontwikkeld dat nauw aansluit bij de in demografische analyses vaker gebruikte cohort- componentenmethode. Deze methode houdt in dat standcijfers worden vergeleken over minimaal twee verschillende tijdstippen. Bij het vergelijken van standcijfers op verschillende tijdstippen wordt dan niet direct een stroom op de arbeidsmarkt waargenomen, maar kan geconstateerd worden dat een bepaalde groep in omvang is toegenomen/afgenomen en er dus individuen moeten zijn in- of uitgestroomd. Op deze wijze kunnen netto stromen worden geconstrueerd.

Sinds kort beschikt het ROA over paneldata waaruit mobiliteitstromen op de arbeidsmarkt kunnen worden afgeleid. Het betreft data uit het roterend panel van de EBB die nu beschikbaar zijn voor de periode 2001-2008. Het EBB-panel is een representatieve steekproef waarvan voor op vijf peilmomenten gedurende een jaar (d.w.z. vijf 2 
achtereenvolgende kwartalen) het beroep van de hoofdwerkkring bekend is. Uit een eerdere publicatie van het CBS en ROA (Bierings et al., 2009) mag worden afgeleid de panelgegevens een goede databron vormen om de beroepenmobiliteit in Nederland mee vast te stellen.

De vraag is nu in hoeverre deze panelgegevens gebruikt kunnen worden om de vervangingsvraagmethodiek te verbeteren. In dit werkdocument wordt een eerste stap gezet richting de ontwikkeling van een nieuwe vervangingsvraagmethodiek. Allereerst is het noodzakelijk om de analyses van de beroepenmobiliteit van het Bierings et al. (2009) verder uit te breiden zodat een beter beeld kan worden verkregen van de bruikbaarheid van de panelgegevens voor de vervangingsvraagprognoses. Om aan te sluiten bij de huidige vervangingsvraagmethodiek dienen de stroomcijfers nader te worden uitgesplitst naar cohorten. Ten tweede wordt in dit rapport uitgebreid ingegaan op de relatie tussen de netto en bruto stromen. Terwijl in Bierings et al. (2009) uitsluitend is gekeken naar bruto stromen, kunnen op basis van het EBB-panel ook netto stromen worden afgeleid. Dit is relevant omdat de aanpassingen van de vervangingsvraagmethodiek zich in eerste instantie zal richten op netto stromen om de vergelijkbaarheid met de cohortcomponentenmethode te behouden. Hierbij speelt mee dat er (vooralsnog) gestreefd wordt naar een zekere mate van consistentie van de vervangingsvraagprognoses over de tijd. Belangrijk is tevens dat het implementeren van bruto in plaats van netto stromen niet alleen leidt tot een andere definitie van de vervangingsvraag (en daarmee andere prognoses), maar ook consequenties heeft voor de definities van de overige vraag- en aanbodcomponenten in het prognosemodel (uitbreidingsvraag en instroom). Deze zullen dus met de introductie van bruto stromen in de vervangingsvraagmethodiek ook aangepast moeten worden.

Zoals eerder gezegd dient dit rapport gezien te worden als een eerste stap richting een vernieuwde vervangingsvraagmethodiek. In hoofdstuk 2 van dit document wordt ingegaan op het EBB-panel en de cohort- componentenmethode. Allereerst worden de kenmerken van het EBB-panel kort besproken. Daarbij wordt eveneens ingegaan op de eerdere resultaten in het eerder uitgebrachte CBS/ROA-rapport (Bierings et al., 2009). Vervolgens worden voor- en nadelen van de cohortcomponentenmethode afgezet tegen die van de panelaanpak. Specifiek wordt ingegaan op de effecten van de steekproefonzekerheid op de waargenomen mobiliteitstromen. Als laatste wordt kort ingegaan op de consequenties van het implementeren van bruto stromen in het prognosemodel. In hoofdstuk 3 worden vervolgens de resultaten getoond van de analyses van de netto en bruto stromen op basis van het EBB-panel. Tot slot volgt een samenvattende conclusie. 


\section{EBB-panel en de cohortcomponentenmethode}

\subsection{EBB-panel en mobiliteitstromen}

Uit de Enquête Beroepsbevolking (EBB) zijn panelgegevens over beroepenmobiliteit beschikbaar. Het roterend panel van steekproefpersonen (representatief voor de Nederlandse bevolking) wordt voor maximaal 1 jaar op ten hoogste 5 peilmomenten gevolgd. ${ }^{1}$ De wijze waarop in de EBB het beroep wordt vastgesteld komt overeen met die in andere surveys zoals de Current Population Survey (CPS) in de Verenigde Staten. Transities in en uit een beroep worden daarbij alleen voor de hoofdwerkkring waargenomen. Maximaal zijn 4 transities van een persoon waar te nemen in een jaar.

Niet voor alle respondenten op een bepaald peilmoment zijn vervolgmetingen beschikbaar. Dat heeft ten eerste te maken met het rotatieschema zoals dat in de EBB voor het panel wordt toegepast. In Tabel 1 is het EBB-rotatieschema weergegeven. leder kwartaal is opgedeeld in 5 ongeveer even grote groepen die met een letter zijn aangegeven. Het rotatieprincipe werkt zo dat in kwartaal // de respons a uit kwartaal / vervangen wordt door $\mathrm{F}$, in kwartaal III de respons b uit kwartaal II vervangen door G, enz. ledere groep wordt zodoende 5 keer gepeild. Van de oorspronkelijke groep in een kwartaal is een jaar later een vijfde over.

Tabel 1

Rotatie panel EBB *)

$\begin{array}{cccccc}\text { Kwartaal } & & & & \\ \text { IV } & \text { I } & \text { II } & \text { III } & \text { IV } & \text { I } \\ \text { D } & \text { E } & \text { F } & \text { G } & \text { H } & \text { I } \\ \text { C } & \text { d } & \text { e } & \text { f } & \text { g } & \text { H } \\ \text { B } & \text { c } & \text { d } & \text { e } & \text { e } & \text { F } \\ \text { A } & \text { b } & \text { c } & \text { d } & \text { d } & \text { E }\end{array}$

*) Hoofdletters:= eerste peiling volgens CAPI; 4 vervolgpeilingen:= kleine letters volgens CATI

Een andere vorm van "uitval" ontstaat wanneer personen besluiten niet meer aan de enquête deel te nemen. Dit is wat we normaal gesproken onder paneluitval verstaan. Dit heeft tot gevolg dat niet van alle starters alle transities in een jaar worden waargenomen. Een specifiek probleem doet zich voor wanneer de paneluitval selectief is.

In 2009 is door het CBS en het ROA een studie uitgevoerd waarin is gekeken of op basis van de panelgegevens uit de Enquête Beroepsbevolking (EBB) een adequaat beeld van de beroepenmobiliteit in Nederland kan worden gegeven (Bierings et al., 2009). Daartoe heeft de desbetreffende studie uitvoerig geanalyseerd in hoeverre de EBB-paneldata betrouwbaar zijn voor de periode 2002-2005 en is de plausibiliteit van de mobiliteitstromen onderzocht. Uit de studie blijkt dat in het algemeen kan worden gesteld dat de kwaliteit van de EBBpaneldata goed is voor de onderzochte periode. De omvang van de paneluitval is niet bijzonder groot en is redelijk constant over de verschillende peilingen. Desalniettemin is er

1. Daarbij is de afstand tussen de peilmomenten ongeveer even groot, namelijk 3 maanden. 
sprake van selectiviteit in de paneluitval. Vooral de uitval onder mobielere groepen is naar verhouding groot: allochtonen, jongeren (15-24 jaar) en lager opgeleiden. Ook kan uitval van personen die zijn verhuisd tot onderschatting van beroepenmobiliteit leiden. Dit geldt met name wanneer de verhuizing het gevolg is van een verandering van beroep. Deze indicaties hebben ertoe geleid dat door het CBS een voorstel is gedaan voor een nieuw weegschema om de beroepenmobiliteit te schatten.

Daarnaast blijkt uit Bierings et al. (2009) dat de uitkomsten over beroepen op 1-digitniveau op basis geen implausibele uitkomsten opleveren. De richting van de mobiliteitsstromen binnen de EBB is eveneens zoals verwacht. Personen met een elementair of lager beroep zijn vaker mobiel en worden vaker werkloos of inactief. Beroepverlaters vertrekken vooral naar beroepen met aangrenzende niveaus en dezelfde richting als in het initiële beroep. Mensen die werkloos en non-participant zijn, stromen vaak uit naar beroepen op lagere niveaus. Deze mobiliteitstromen worden zowel gevonden op 1-digit als op 3-digitniveau. De uitsplitsing van de beroepenmobiliteit in het EBB-panel over groepen met verschillende achtergrondkenmerken laat eveneens geen verrassingen zien. Vrouwen zijn in het EBBpanel iets mobieler dan mannen en jongeren en ouderen treden vaker uit de arbeidsmarkt door studie of pensionering. Jongeren in de leeftijd van 15 tot en met 24 jaar zijn het meest mobiel.

Kort samengevat wordt uit de eerdere studie van Bierings et al. (2009) duidelijk dat de EBBpaneldata geschikt zijn voor analyses van mobiliteitstromen op de arbeidsmarkt, waardoor er een additionele databron beschikbaar is gekomen voor de vervangingsvraagprognoses van het ROA. Een kanttekening is dat bij het gebruik van het EBB-panel in plaats van standcijfers uit de EBB eveneens gewogen dient te worden voor de selectieve paneluitval. Het CBS is stelt een weging samen voor het publiceren van statistieken over beroepenmobiliteit. Echter, voor de specifieke doeleinden van het ROA zal een aparte weging noodzakelijk zijn. Zodra deze weging gereed is, kan grotendeels gecorrigeerd worden voor de effecten van de selectieve uitval op de mobiliteitstromen.

\subsection{Methodiek cohortcomponentmethode en gebruik panelgegevens}

Omdat de vervangingsvraag direct voortkomt uit stromen op de arbeidsmarkt, ligt het voor de hand om voor het bepalen van de vervangingsvraag bruto stroomcijfers te hanteren. Deze cijfers waren echter in het verleden niet beschikbaar en daarom is er een methodiek geformuleerd die op basis van een vergelijking van standcijfers van de Enquête Beroepsbevolking (EBB) tussen verschillende jaren een indicatie geeft van de stromen die tussentijds plaats hebben gevonden (zie Willems en De Grip, 1993). Deze methodiek wordt ook wel de cohortcomponentenmethode genoemd. Door de standcijfers per geslacht op te splitsen in leeftijdsgroepen, kan per leeftijdscategorie de netto in- of uitstroom worden vastgesteld. De uitstroomcoëfficiënten, zoals ze zijn vastgesteld voor de meetperiode, worden vervolgens geprojecteerd op de leeftijdsverdeling in het basisjaar, om zo een prognose te kunnen maken van de uitstroom in de komende jaren. Deze prognose wordt gecorrigeerd voor de verwachte veranderingen in de arbeidsparticipatie per geslacht/leeftijdcohort voor de gehele beroepsbevolking. Naast deze participatiecorrectie 
vindt ook een vergelijkbare correctie plaats voor de conjuncturele situatie in de analyseperiode.

Elke methodiek voor het bepalen van de beroepenmobiliteit heeft zijn voor- en nadelen. Zoals eerder is aangegeven is bij gebruik van paneldata sprake van selectieve paneluitval. Als men echter een goed beeld heeft van de selectiviteit van de uitval, dan kan men daar door middel van een weging voor corrigeren.

Ook de cohortcomponentenmethode die voor de vervangingsvraagprognoses gebruikt wordt kent een aantal problemen. ${ }^{2}$ Eén van deze problemen is dat er sprake is van een zekere steekproefonzekerheid. Deze steekproefonzekerheid ontstaat vanwege het feit dat de EBB een steekproef is uit de populatie van alle mensen die 15 jaar en ouder zijn in Nederland. leder onderzoek op basis van een steekproef geeft echter afwijkingen ten opzichte van de werkelijkheid, ook wel steekproefonzekerheid genoemd. De onzekerheid is groter naarmate de steekproef kleiner is. Omdat de cohortcomponentenmethode gebaseerd is op de vergelijking van (minimaal) twee standcijfers, die door de opsplitsing in geslachts- en leeftijdsgroepen veelal betrekking hebben op kleine groepen, is de kans aanwezig dat de steekproefonzekerheid een effect heeft op de mobiliteitsstromen en de uitstroomcijfers. Immers, als eenmalig door de steekproeftrekking gemiddelden afwijken ten opzichte van het populatiegemiddelde en vervolgens in een tweede trekking het gemiddelde niet afwijkt, dan worden mobiliteitsstromen waargenomen als gevolg van de steekproeftrekkingen terwijl er in werkelijkheid geen sprake hoeft te zijn van mobiliteit.

In het verleden is getracht op een drietal wijzen om het effect van de steekproefonzekerheid op de vervangingsvraagprognoses te reduceren. Allereerst is het probleem van de steekproefonzekerheid aangepakt door meerdere waarnemingsjaren te vergelijken, in plaats van de standcijfers van slechts twee jaren.

Ten tweede zijn de prognoses gebaseerd op een econometrisch model dat expliciet met meetfouten, waaronder steekproefonzekerheid, rekening houdt. De prognoses waren voorheen gebaseerd op een methode die ontwikkeld is door Willems (1996) die is gebaseerd op een random-coëfficiëntenmodel, dat naarmate een stroomcoëfficiënt minder nauwkeurig wordt gemeten, sterker terugvalt op de gemiddelde coëfficiënt voor de betreffende groep bij alle beroepsklassen of alle opleidingstypen. Dit houdt in dat wanneer een stroomcoëfficiënt voor een bepaalde beroepsgroep of opleidingstype te sterk afwijkt, deze wordt 'overruled' door een meer gematigde uitkomst van een overkoepelende groep beroepsgroepen of opleidingstypen. Zo kan bijvoorbeeld een onbetrouwbare uitkomst voor de lassers en constructie medewerkers worden vervangen door de uitstroomcoëfficiënt van het (hogere) cluster technische en industrieberoepen.

In de meest recente prognoses is deze methode aangepast door gebruik te gaan maken van een fixed effects model, waarbij de netto in- of uitstroomratio's worden verklaard op basis van de beroepsspecifieke afwijkingen per geslacht en leeftijdsklasse van de gemiddelde in-

2. Zie Montizaan (2009) voor meer informatie. 
of uitstroompatronen uit de totale werkzame bevolking (Cörvers et al., 2008). Een dergelijke aanpak garandeert dat de som van de netto stromen over de beroepen overeenkomt met de totale netto in- of uitstroom met als voordeel dat de geschatte parameters in het fixed effects model stabieler zijn dan in het random-coëfficiëntenmodel.

Ten derde worden er zogenaamde plausibiliteittoetsen uitgevoerd. Bij de uitgevoerde prognoses werd de plausibiliteit van de afzonderlijke parameters getoetst en indien prognose-uitkomsten niet plausibel waren, werden zij dienovereenkomstig aangepast (zie Clements, 1995) voor een discussie over het oordeel van een deskundige bij onzekere prognosetechnieken). Hierbij dient echter te worden opgemerkt dat de plausibiliteittoetsen niet uitsluitend voor steekproefonzekerheid corrigeren.

Hoewel de drie correcties leiden tot een reductie van het effect van de steekproefonzekerheid, kan het effect van jaarlijkse afwijkingen in de steekproef ten opzichte van de populatie niet volledig worden uitgebannen in de cohortcomponentenmethode. Bij gebruik van de panelgegevens van de EBB heeft de steekproefonzekerheid daarentegen geen effect op de netto in- en uitstroom. Dit is dus een duidelijk voordeel van het gebruik van paneldata voor het bepalen van de beroepenmobiliteit. Hoewel ook voor het EBB-panel geldt dat elk jaar de steekproef jaarlijks kan verschillen van de populatie, zijn de stroomcijfers voor een bepaald jaar echter gebaseerd op maar één steekproef. Aangezien dezelfde mensen over één jaar worden gevolgd kan de jaarlijkse in- en uitstroom in een beroep of inactiviteit worden bepaald om voor dezelfde mensen na te gaan in welk beroep (inactiviteit ) zij op periode $t=1$ werkzaam waren en in welk beroep (inactiviteit) zij werkzaam waren in periode $t=5$. Veranderingen in de beroepencodes geven aan dat mensen uit een bepaald beroep zijn uitgestroomd en vervolgens in welk beroep zij zijn ingestroomd. De netto uitstroom wordt vervolgens bepaald door voor een bepaald beroep de bruto instroom af te trekken van de bruto uitstroom. Op deze manier kunnen dus eveneens netto stromen worden afgeleid met als groot voordeel dat in tegenstelling tot bij de cohortcomponentenmethode geen gebruik hoeft te worden gemaakt van een tweede steekproef. Daardoor kan de steekproefonzekerheid geen effect hebben op de stroomcijfers en zijn de vervangingsvraagprognoses in mate mindere gevoelig voor de steekproeftrekking.

\subsection{Netto en bruto stromen}

Naast het feit dat bij het afleiden van de mobiliteitstromen op basis van paneldata de steekproefonzekerheid geen effect kan hebben op de stroomcijfers is het eveneens een voordeel dat bruto stromen worden geobserveerd en daaruit netto stromen kunnen worden afgeleid.

Als eerste stap in het proces van het omvormen van het prognosemodel, is het van belang om te kijken naar een mogelijke implementatie van de netto stromen op basis van het EBBpanel in de vervangingsvraagmethodiek. Een directe implementatie van de bruto stromen zou niet alleen gevolgen hebben voor de vervangingsvraagmethodiek, maar ook voor de methodiek voor het bepalen van de uitbreidingsvraag en de arbeidsmarktinstroom. Wat betreft de vervangingsvraagmethodiek dient te worden opgemerkt dat het gebruik van bruto 
stromen geen effect zal hebben op de uitbreidingsvraag naar beroep, maar dat de methodiek voor de uitbreidingsvraag naar opleiding dient te worden aangepast. Dit omdat bij de berekening van de uitbreidingsvraag naar opleiding onder andere gecorrigeerd wordt voor substitutie-effecten. In het huidige prognosemodel is de vervangingsvraag een belangrijke determinant van deze substitutie-effecten. Ten tweede zou bij het gebruik van bruto stromen de arbeidsmarktinstroom anders dienen te worden bepaald. Bij gebruik van netto stromen is het niet noodzakelijk om te berekenen hoeveel mensen die reeds werkzaam waren vervolgens in een bepaald beroep instroomden, maar bij gebruik van bruto stromen is dit wel noodzakelijk. Bij het hanteren van bruto stromen voor vervangingsvraagprognoses, zou de arbeidsmarktinstroom niet alleen bepaald dienen te worden voor schoolverlaters maar ook expliciet voor herintreders, baanwisselaars tussen beroepsgroepen, etc.

Desondanks kan de beschikbaarheid van de bruto stromen leiden tot een beter inzicht in de ontwikkelingen in de netto stromen en biedt het EBB-panel mogelijkheden om uitgebreid de relatie tussen bruto- en netto stromen te analyseren.

\section{Netto en bruto stromen op basis van het EBB-panel}

Zoals reeds eerder gezegd is het noodzakelijk om als eerste stap voor een nieuwe vervangingsvraagmethodiek de analyses van de beroepenmobiliteit van het CBS/ROArapport (Bierings et al., 2009) verder uit te breiden zodat een beter beeld kan worden verkregen van de bruikbaarheid van de panelgegevens van de EBB voor de vervangingsvraagprognoses. Om aan te sluiten bij de huidige vervangingsvraagmethodiek dienen de mobiliteitscijfers nader te worden uitgesplitst naar cohorten. Daarnaast werd in het CBS/ROA-rapport uitsluitend gekeken naar bruto stromen. Echter, het is eveneens relevant om na te gaan in hoeverre de netto stromen plausibel zijn en hoe zij in verhouding staan tot de bruto stromen. Daarom wordt in dit hoofdstuk voor een aantal typische beroepsgroepen gekeken naar de bruto instroom en uitstroomcijfers per cohort (met onderscheid op basis van 5-jaars leeftijdsklassen en geslacht zoals in de cohort componentenmethode) en worden vervolgens netto stromen afgeleid. Het betreft hier een selectie van de bestaande 127 beroepsgroepen, gespreid over vrouwen- of mannenberoepen, en beroepsgroepen met lager, middelbaar of hoger opgeleiden.

Voor onze analyses is gebruik gemaakt van data uit het EBB-panel voor de jaren 2001 tot en met 2007. De data is gewogen door gebruik te maken van de jaarweging van het EBBpanel. ${ }^{3}$ Een belangrijk selectiecriterium is dat alleen personen zijn meegenomen waarvoor zowel in kwartaal 1 als ook in kwartaal 5 een beroepencode wordt waargenomen. Om zo dicht mogelijk aan te sluiten bij de huidige prognosemethodiek, zullen we uitsluitend kijken naar de beroepenmobiliteit over een periode van 1 jaar. We kijken dus niet beroepenmobiliteit tussen kwartalen. Aangezien maar weinig mensen in het korte tijdsbestek

3. Deze weging dient in een later stadium nog aangepast te worden in verband met de selectiviteit van paneluitval. 
van een jaar vaker dan 1 keer mobiel zijn, zal de analyse van de beroepenmobiliteit tussen jaren echter maar weinig afwijken van een analyse tussen kwartalen.

Instroom in een specifiek beroep wordt dus bepaald door vanuit kwartaal 5 te kijken (dit bepaalt het beroep waarvan de instroom berekend wordt) naar het aantal personen dat in kwartaal 1 NIET in hetzelfde beroep was. Uitstroom is het tegenovergestelde. Uitgaande van kwartaal 1 wordt gekeken naar het aantal personen dat het beroep tot kwartaal 5 heeft verlaten. De bruto en netto stromen worden vervolgens in figuren getoond. De stroomcijfers zijn per cohort en geslacht berekend als percentage over het totaal aantal werkenden per cohort en geslacht. We berekenen de percentages per cohort en geslacht over de 7 jaar waarvoor de data beschikbaar zijn. Het betreft dus een gemiddeld percentage over de 7 jaar. Op deze manier kan een beeld verkregen worden van de relatieve grootte van de bruto in- en uitstroom alsmede de netto uitstroom per cohort en geslacht. De figuren laten daarnaast zien hoeveel mensen per cohort en geslacht werkzaam zijn in een specifiek beroep. Ook hier betreft het een gemiddeld aantal over de 7 jaar waarvoor data beschikbaar zijn. Op basis van deze aantallen kan indirect een beeld worden verkregen van de relevantie van de gepercenteerde stroomcijfers. Voor de interpretatie van de aantallen in relatie tot de stroomcijfers dient echter te worden opgemerkt dat de aantallen geen goede indicatie geven van de stromen, maar vooral een cross-sectionele doorsnede geven van hoeveel mensen in specifieke cohorten gemiddeld werkzaam zijn in een beroep.

Figuur 3.1 laat de bruto stromen, de netto stroom en de aantallen werkenden zien voor de leraren basisonderwijs. Linksboven en -onder worden de bruto stromen weergegeven voor mannen en vrouwen. De linkeras van deze figuren laat de percentages zien van het aantal mensen dat in- of uitstroomt (als percentage van totaal aantal werkenden in een specifiek cohort). De rechteras geeft voor elk cohort het aantal mensen weer dat werkzaam is als leraar basisonderwijs. Rechtsboven en -onder worden de netto stromen voor mannelijke en vrouwelijke leraren basisonderwijs weergegeven. Figuur 3.1 laat zien dat de stroomcijfers en de aantallen op basis van het EBB-panel voor leraren basisonderwijs vrij plausibel zijn.

Wat betreft het aantal werkenden per cohort, blijkt dat meer vrouwen dan mannen werkzaam zijn als leraar basisonderwijs. Dit gegeven wordt ook gevonden op basis van de standcijfers. Daarnaast valt op dat dit beroep een vrij hoge mate van vergrijzing kent. Voor de mannen wordt het grootste aantal werkenden waargenomen voor het cohort dat tussen 50 en 54 jaar oud is. Voor de vrouwen is het cohort 45-49 jaar het grootst. Zoals kan worden verwacht is bijna niemand werkzaam als leraar basisonderwijs onder de leeftijd van 20 jaar en is het aantal werkenden in het cohort dat veelal met pensioen kan (60-64 jaar) een stuk lager.

De stroomcijfers laten eveneens plausibele resultaten zien. Voor zowel mannen als vrouwen wordt voor de cohorten tussen de 15 en 24 jaar een hoge bruto instroom gemeten. Voor de oudere cohorten is de instroom laag en vrij stabiel. Alleen voor mannen tussen de 60 en 64 jaar wordt een iets hogere instroom waargenomen. Een mogelijke verklaring hiervoor is dat oudere leraren met pensioen gaan en vervolgens weer opnieuw in dienst worden genomen om een (tijdelijk) gat in de personeelsvoorziening te dichten. Een andere mogelijkheid is dat directeuren van basisscholen net voor hun pensioen gaan afbouwen, hun 
directietaken overdragen en weer gaan les geven. De bruto uitstroom is voor zowel mannen als vrouwen vrij constant over de cohorten. In lijn met de verwachtingen is de bruto uitstroom hoger voor mensen die tussen de 60 en 64 jaar oud zijn, aangezien de meeste leraren basisonderwijs in dit leeftijdscohort in aanmerking komen voor vervroegde pensionering. De netto stroomcijfers in de rechter figuren laten zien dat er sprake is van een netto instroom vooral alle cohorten tot aan de leeftijd van 25 jaar. Ofwel, voor deze cohorten geldt dat er meer mensen instromen als leraar basisonderwijs dan dat er uitstromen. Vervolgens blijkt dat de bruto instroom en netto instroom in balans zijn voor de cohorten tussen de leeftijd van 25 jaar en 59 jaar. De netto instroompercentages schommelen voor deze cohorten rond de $0 \%$. Voor de leraren basisonderwijs die tussen de 60 en de 64 jaar oud zijn geldt dat er sprake is van een netto uitstroom. Ofwel voor dit specifieke cohort geldt dat er meer leraren basisonderwijs met (vervroegd) pensioen gaan of arbeidsongeschikt worden dan dat er mensen instromen.

Een andere beroepsgroep waarin doorgaans veel vrouwen werkzaam zijn is therapeuten en verpleegkundigen. Figuur 3.2 laat de bruto stromen, de netto stroom en het aantal werkenden zien. De figuur laat zien dat van alle personen die werkzaam zijn als therapeut of verpleegkundige ongeveer $81 \%$ vrouw is. Dit beroep wordt in tegenstelling tot leraren basisonderwijs gekenmerkt door een vrij normaal verdeelde distributie van het aantal werkenden over de cohorten voor vrouwen. 
Figuur 3.1

Bruto instroom, uitstroom en netto stroom voor Leraren basisonderwijs
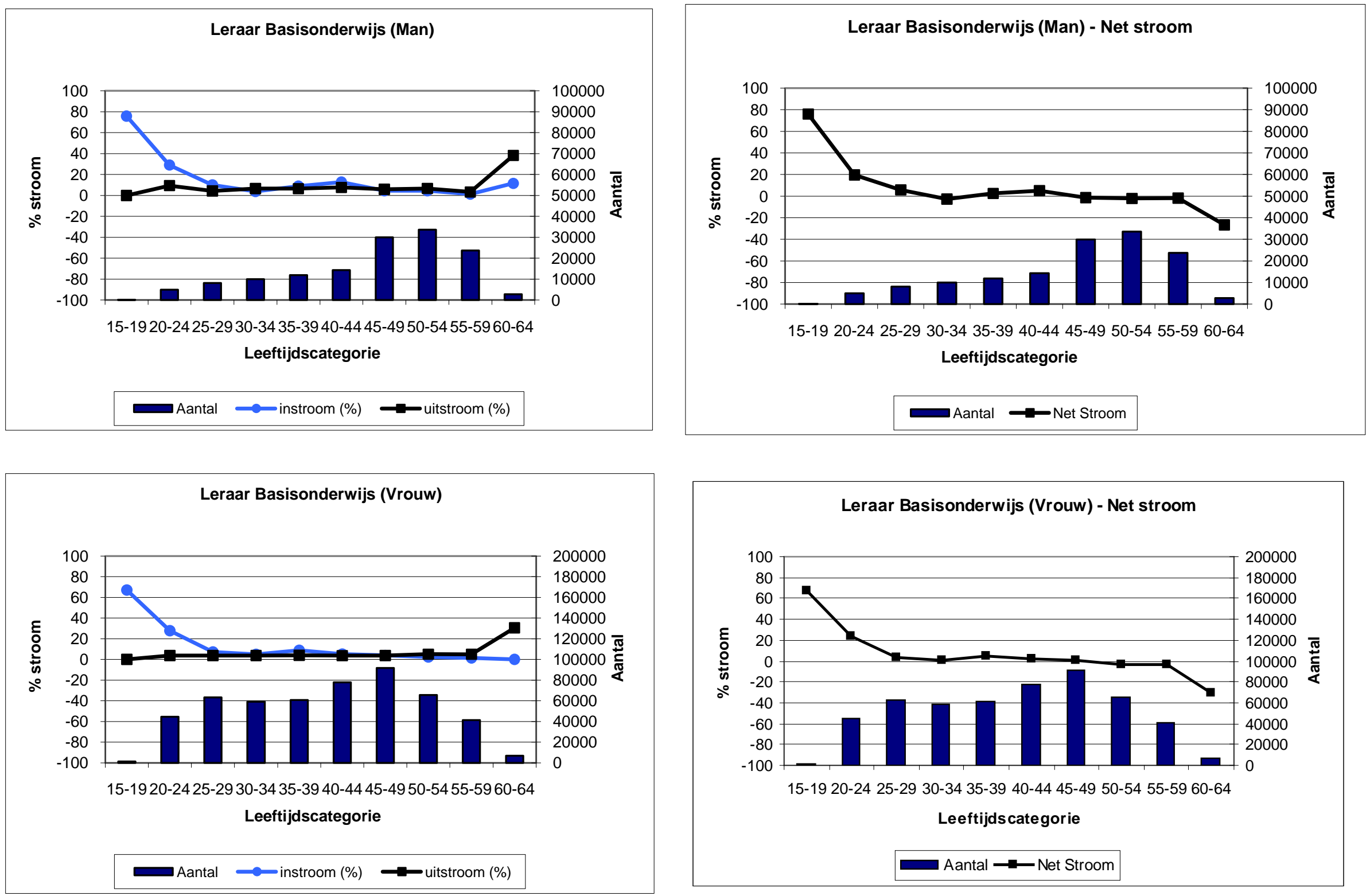
Wat betreft de stroomcijfers kan eenzelfde soort beeld worden waargenomen als bij de leraren basisonderwijs. Voor zowel mannen als vrouwen wordt voor de cohorten tussen de 15 en 24 jaar een hoge bruto instroom gemeten. Voor mannen houdt de hoge instroom zelfs aan tot de leeftijd van 30 jaar. Voor de oudere cohorten, ongeacht het geslacht, is de instroom laag en vrij stabiel. Voor de mannen tussen de 60 en 64 jaar wordt een iets hoger instroompercentage gevonden dan voor het jongere cohort. Dit kan verband houden met de kleine aantallen werkenden in dit cohort, waardoor de enkeling die instroomt wordt gepercenteerd op een klein aantal werkenden. Net zoals bij de leraren basisonderwijs wordt gevonden dat de bruto uitstroom voor zowel mannen als vrouwen vrij constant is over de cohorten. Het effect van vervroegde pensionering op de bruto uitstroom is echter voor de therapeuten en verpleegkundigen minder sterk aanwezig. Voor vrouwen vinden we dat in lijn met de verwachtingen de bruto uitstroom hoger is voor mensen die tussen de 60 en 64 jaar zijn. Voor mannen vinden we dit effect echter niet, wat eveneens verklaard kan worden door de kleine aantallen.

De netto stroomcijfers in de rechter figuren laten zien dat er voor vrouwen sprake is van een netto instroom vooral alle cohorten tot aan de leeftijd van 25 jaar, en voor mannen tot aan de leeftijd van 30 jaar. Aangezien dit de cohorten zijn waarin schoolverlaters beginnen met werken is dit weinig verrassend. Echter, voor de oudere cohorten observeren wij een netto uitstroom. Het is opmerkelijk dat voor de cohorten met een leeftijd tussen 30 jaar en 54 jaar wordt gevonden dat er per saldo meer mensen uitstromen dan instromen en dat dit zowel geldt voor vrouwen en mannen. Het betreft hier mogelijk een beroep waarin veel doorstroom mogelijk is. Voor de vrouwen vinden we dat voor de oudere cohorten (55 jaar en ouder) een iets hogere uitstroom, wat duidt op vervroegde uittreding. 
Figuur 3.2

Bruto instroom, uitstroom en netto stroom voor Therapeuten en verpleegkundigen
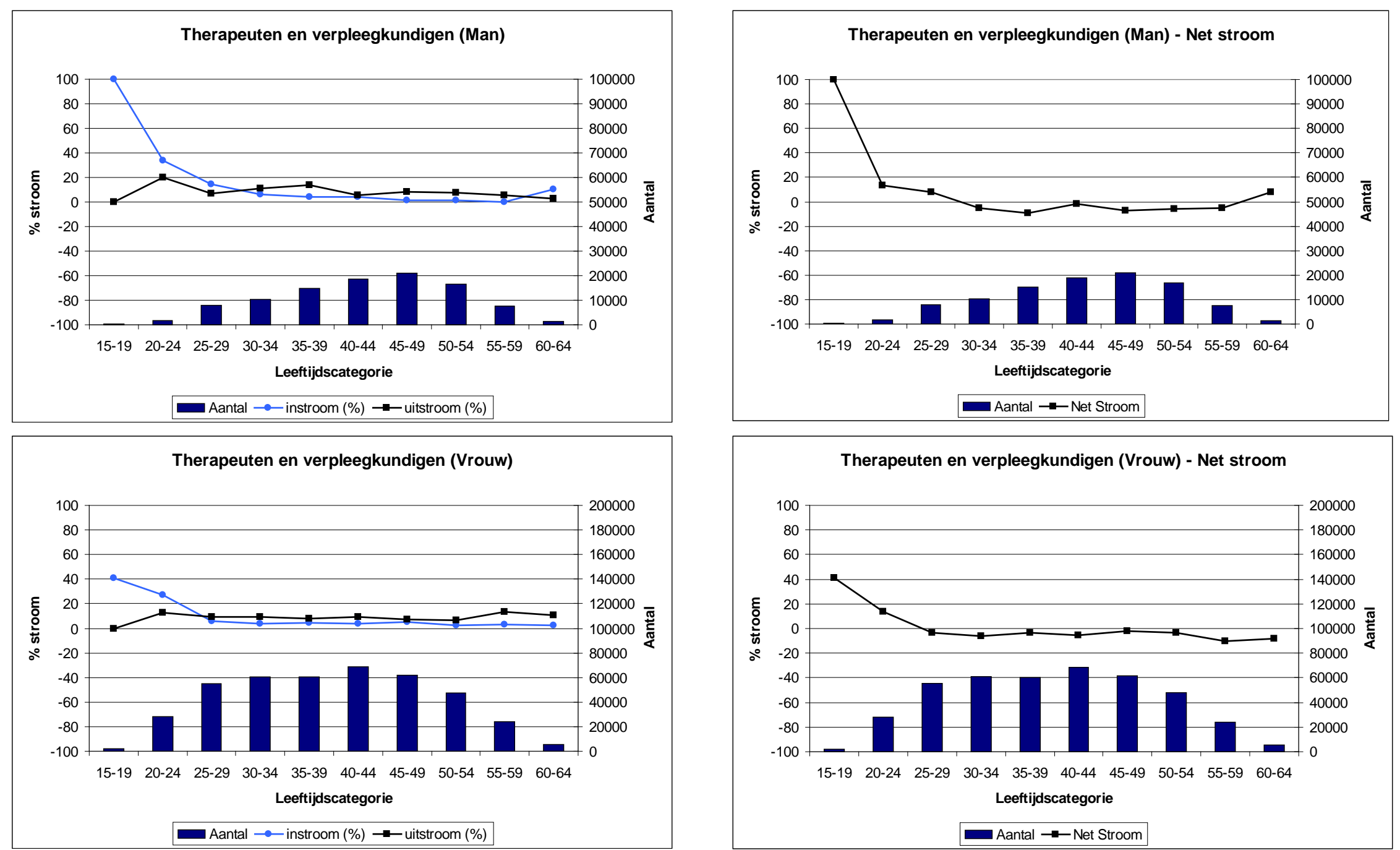
Voor een breder beeld van de mobiliteitsstromen wordt gekeken naar beroepsgroepen waarin traditioneel relatief veel mannen werkzaam zijn. Het betreft de beroepsgroepen bouwvakkers en monteurs. Zoals uit figuur 3.3 en 3.4 kan worden afgelezen is het aantal vrouwen dat werkzaam is in deze beroepen inderdaad zeer klein. In tegenstelling tot de voorheen besproken beroepen valt op dat in deze beroepen relatief veel jonge mannen werken. Dit is weinig verrassend aangezien de opleiding (VMBO of MBO) tot bouwvakker of monteur in veel gevallen op jonge leeftijd wordt afgerond. Daarnaast werken in deze beroepen veel jongeren zonder startkwalificatie.

De bruto instroom en uitstroompercentages voor mannen laten een weinig verrassend beeld zien. Allereerst zie we dat er sprake is van een hoge instroom voor de jonge cohorten en dat de instroom voor cohorten ouder dan 34 jaar stabiliseert. Wat betreft de uitstroom is het opvallend dat deze ook voor de jonge cohorten vrij hoog is. Dit kan echter verklaard worden dat in deze beroepen nog veel werknemers doorleren (of een startkwalificatie behalen), en ander werk gaan doen. Daardoor is de doorstroom in deze beroepen hoog in verhouding met andere beroepen. Voor de cohorten die ouder zijn dan 50 jaar valt een sterke toename van de uitstroom waar te nemen. In deze lichamelijk zware beroepen is vervroegde uittreding doorgaans eerder mogelijk dan in andere beroepen. Daarnaast worden relatief veel oudere werknemers in deze twee beroepsgroepen arbeidsongeschikt.

De netto stromen laten zien dat voor zowel bouwvakkers als monteurs een netto instroom bij de jonge cohorten wordt waargenomen. Voor de cohorten tot en met de leeftijd van 54 jaar houden de bruto uitstroom en instroom elkaar in evenwicht. Vanaf de leeftijd van 55 jaar is er sprake van een netto uitstroom. De netto uitstroom vanaf deze leeftijd is procentueel iets groter voor de monteurs dan voor de bouwvakkers.

Voor de vrouwen daarentegen vinden wij schommelende bruto en de netto stromen voor beide beroepsgroepen. In tegenstelling tot bij de mannen is er geen duidelijke periode van instroom zichtbaar voor de jongere cohorten en een hogere uitstroom voor de oudere cohorten. Dit kan verband houden met de lage aantallen werkzame vrouwen. Overigens, de problematiek van de lage aantallen vrouwen voor de berekening van de beroepenmobiliteit in deze beroepen doet zich niet uitsluitend voor in het EBB-panel, maar bestaat ook bij de cohortcomponentenmethode. 
Figuur 3.3

Bruto instroom, uitstroom en netto stroom voor Bouwvakkers
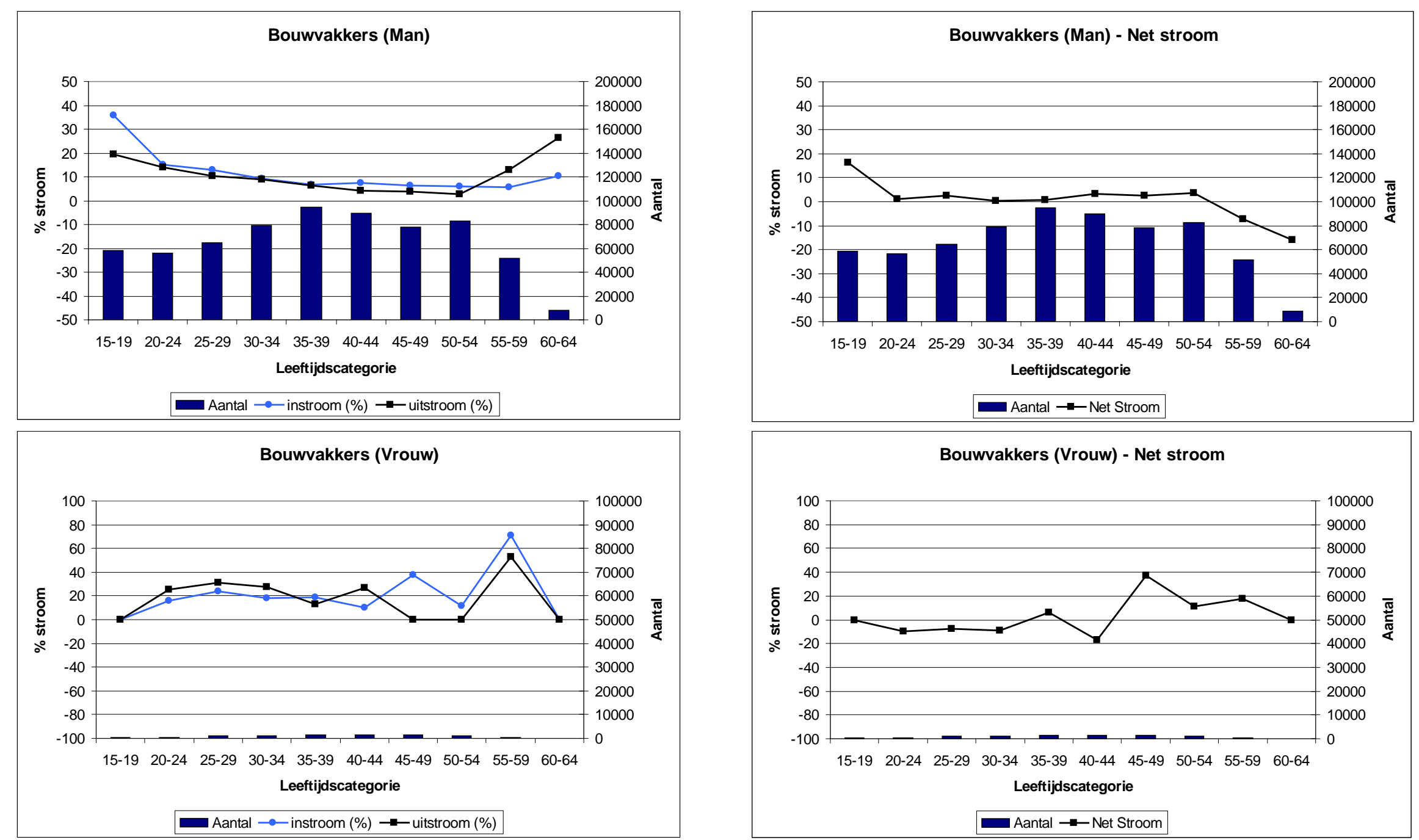
Figuur 3.4

Bruto instroom, uitstroom en netto stroom voor Monteurs
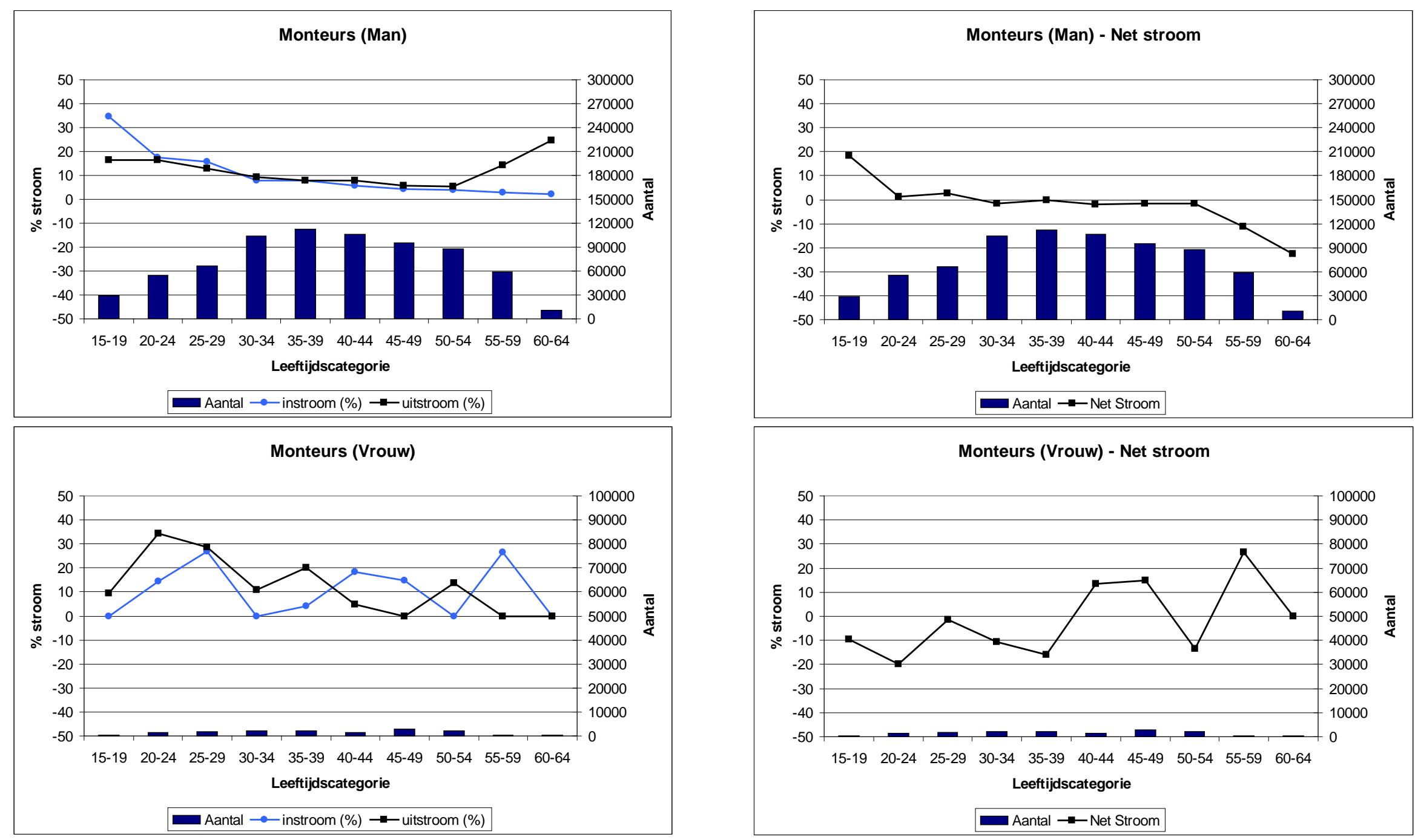
Twee andere beroepsgroepen die hier bekeken worden zijn de commercieel employés en commercieel medewerkers. Deze beroepen zijn interessant omdat het aantal mensen dat hierin werkzaam relatief groot is. Het verschil tussen beide beroepen ligt in het beroepsniveau: commercieel employés is een beroep op MBO-niveau, terwijl commercieel medewerkers een beroep is op HBO-niveau.

Uit de aantallen blijkt dat de verdeling van vrouwen en mannen die werkzaam zijn als commercieel employee nog redelijk gelijk is ten opzichte van de eerder besproken beroepsgroepen. In totaal is ongeveer $40 \%$ van alle commercieel employés vrouw. Bij de commercieel medewerkers is dit percentage slechts $27 \%$. Wel kan uit de leeftijdsverdeling voor de commercieel medewerkers worden afgeleid dat vrouwen waarschijnlijk een inhaalslag maken. De verschillen in aantallen tussen mannen en vrouwen zijn voor de jonge cohorten veel kleiner dan voor de oudere cohorten.

De bruto in- en uitstroompercentages laten voor beide beroepen het standaard patroon zien. De bruto instroom is hoog voor jonge cohorten en is lager voor oudere cohorten. Er valt een lichte daling waar te nemen in de instroom naarmate cohorten ouder zijn. De bruto uitstroom is eveneens hoger voor de jongere cohorten. Vooral voor jongere cohorten geldt dat de beroepenmobiliteit relatief hoog is en dat veel mensen nog zullen doorstromen naar een beroep van een hoger niveau. Daarnaast zullen ook veel jongeren nog van baan veranderen om carrière te maken en en baan te vinden die aansluit bij hun wensen. Het bruto uitstroompercentage is lager naarmate een cohort ouder is. Voor het cohort met de leeftijd tussen 60 en 64 jaar is de bruto uitstroom weer beduidend hoger als gevolg van de (vervroegde) uitreding van werknemers.

De bruto stromen leiden uiteindelijk tot netto stromen die eenzelfde beeld vertonen als voor de eerder besproken beroepsgroepen. Voor zowel commercieel employés als commercieel medewerkers blijkt dat er sprake is van een netto instroom van de cohorten met een leeftijd tot 35 jaar. Alleen voor vrouwelijke commerciële medewerkers is reeds sprake van een netto uitstroom voor het cohort tussen 25 en 29 jaar. Mogelijk speelt hierbij mee dat in dit specifieke cohort veel vrouwen kinderen krijgen en daarom (tijdelijk) de arbeidsmarkt verlaten ('kinderdal'). Voor het cohort met een leeftijd van 60 jaar of ouder is sprake van een netto uitstroom, ongeacht het geslacht. 
Figuur 3.5

Bruto instroom, uitstroom en netto stroom voor Commercieel employés
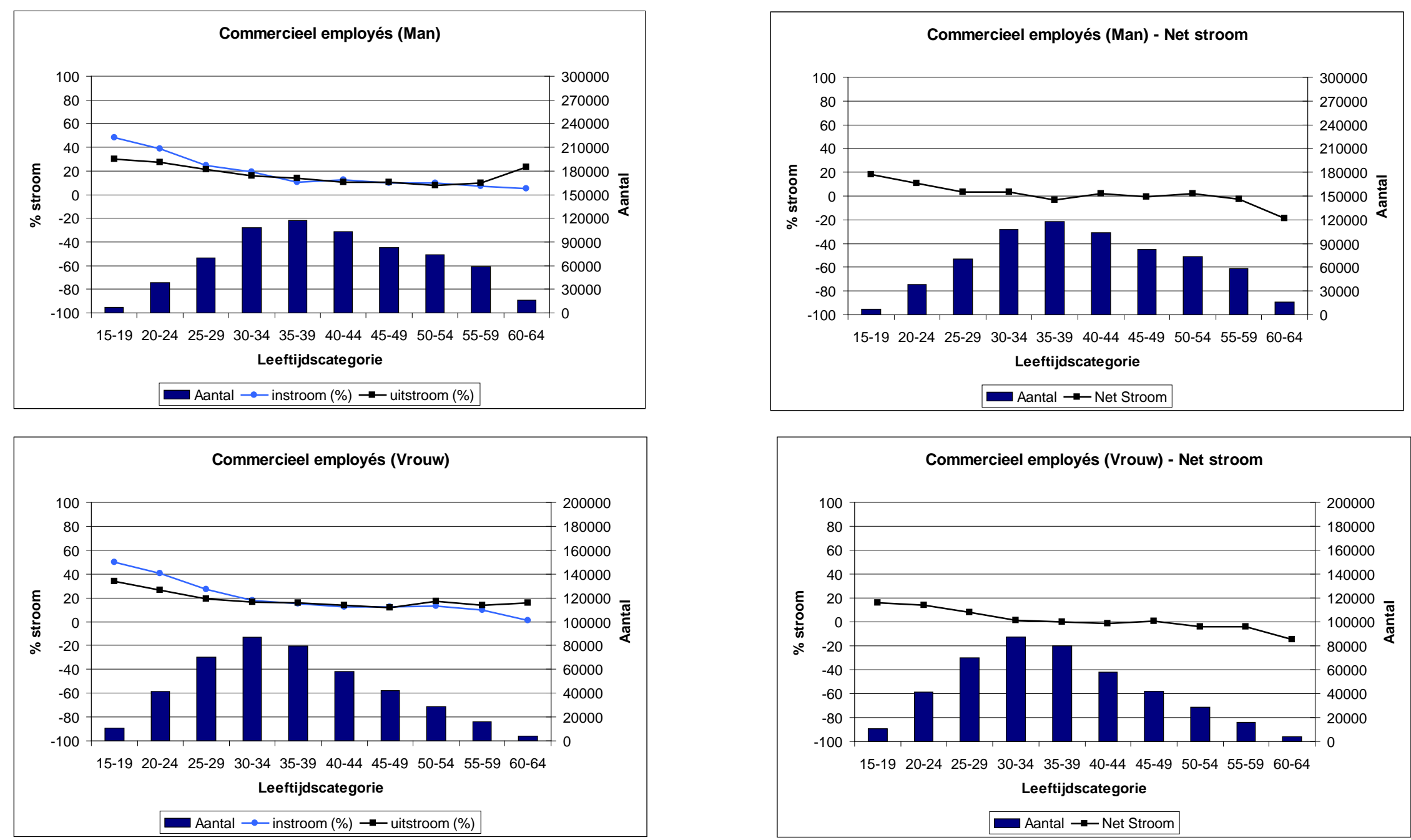
Figuur 3.6

Bruto instroom, uitstroom en netto stroom voor Commercieel medewerkers
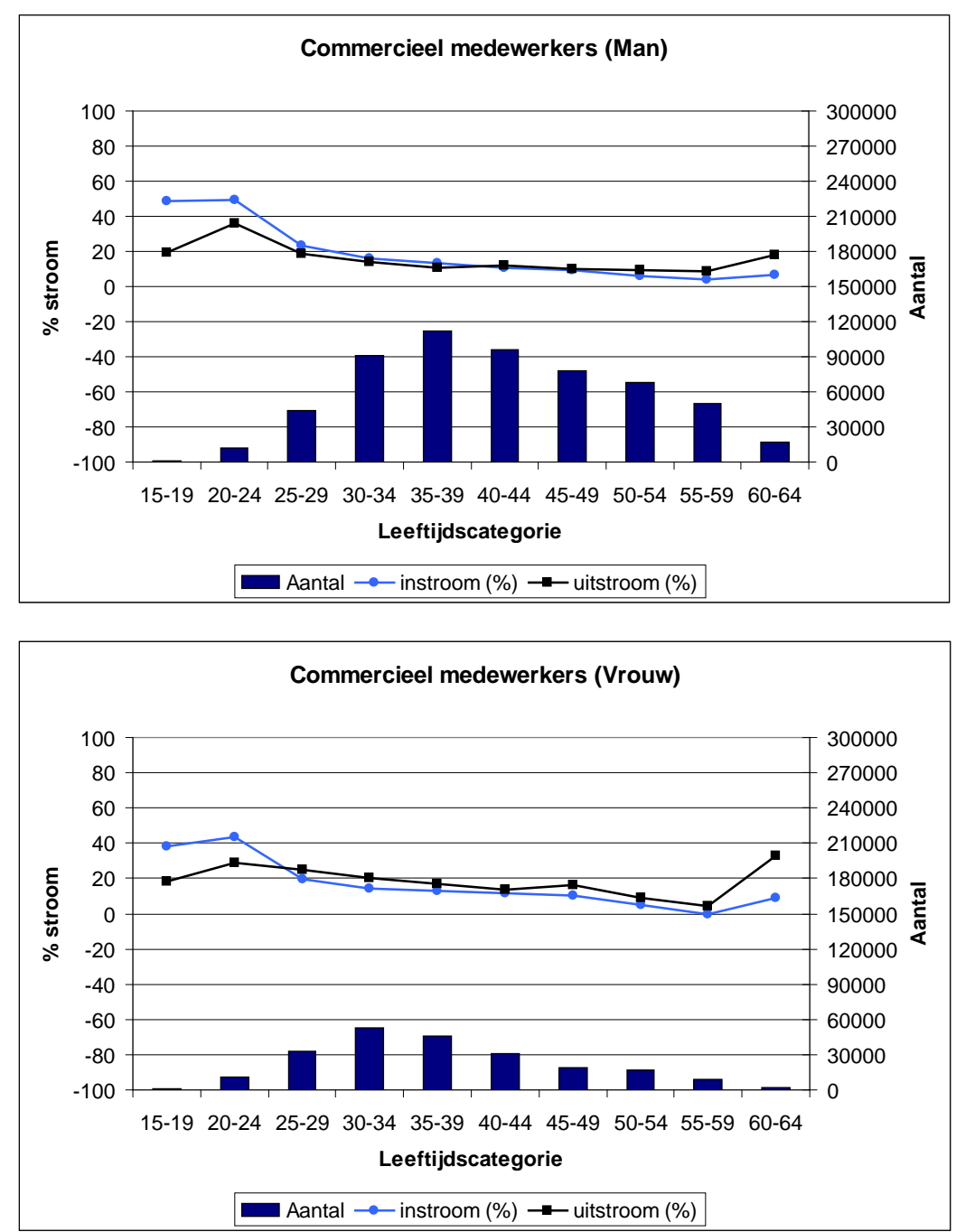
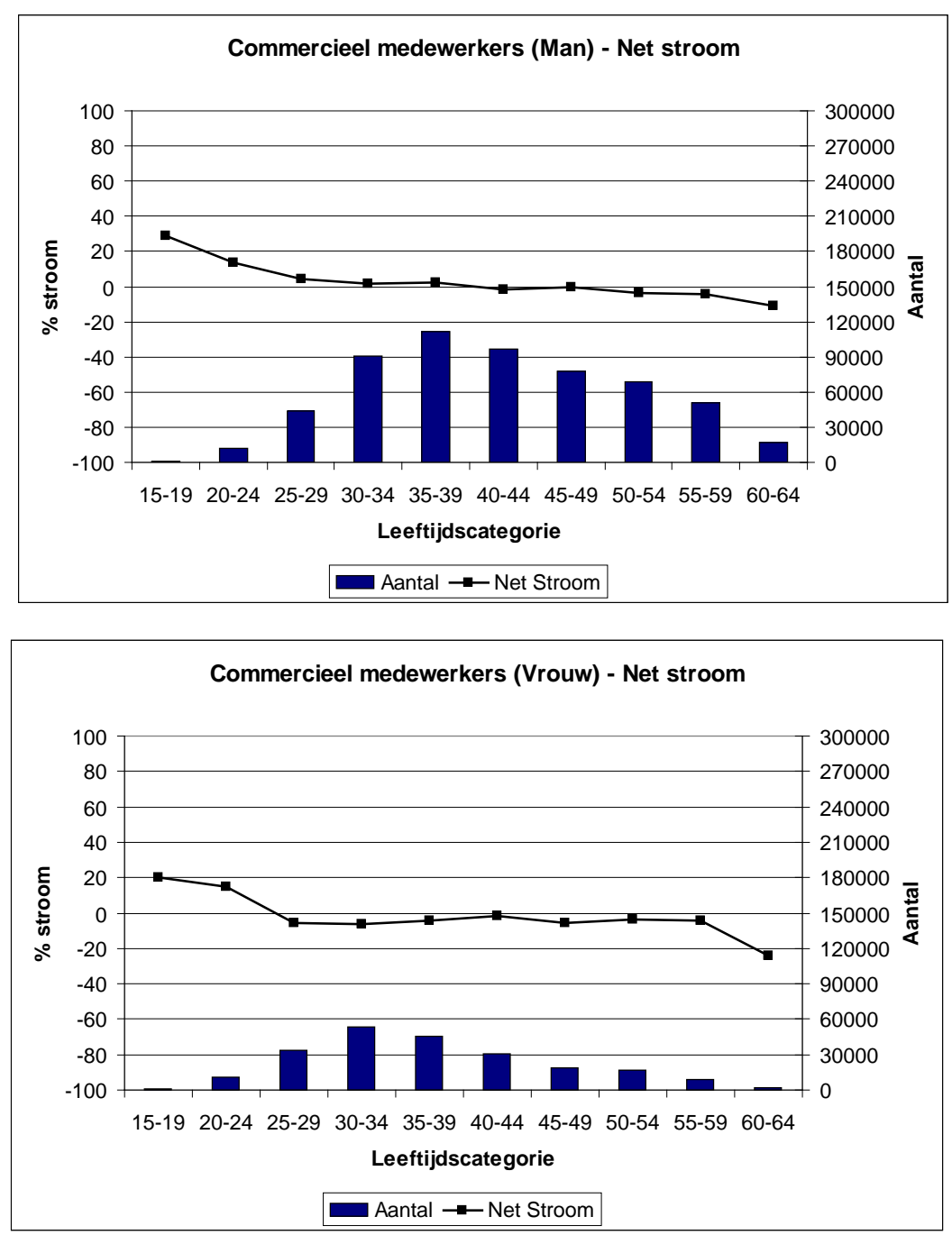
De laatste twee beroepsgroepen die hier worden uitgelicht zijn de agrarische arbeiders en de artsen. In de eerste beroepsgroep zijn vooral laagopgeleiden en scholieren werkzaam, terwijl artsen juist hooggeschoold zijn. Deze twee beroepsgroepen zijn dus twee interessante uitersten. Figuur 3.7 en 3.8 laten de aantallen en de bruto- en netto stromen zien.

Uit figuur 3.7 blijkt uit de aantallen werkenden per cohort dat het beroep agrarische arbeiders afwijkt van de beroepsgroepen die wij tot dusver hebben besproken. Het grootste cohort werkenden in deze beroepsgroep bestaat uit personen die 15 tot en met 19 jaar oud zijn, zowel voor mannen als vrouwen. Dit duidt erop dat veel scholieren en studenten werkzaam zijn als agrarische arbeider en zo proberen bij te verdienen naast hun studie. Het specifieke karakter van deze beroepsgroep leidt tevens tot afwijkende mobiliteitsstromen. Voor mannen is de instroom het hoogst voor de cohorten die jonger zijn dan 25 jaar. Voor het cohort dat tussen de 25 en 29 jaar oud is de instroom veel lager, terwijl voor de oudere cohorten de instroom weer iets hoger ligt. Dit duidt erop dat jongeren tijdens hun studie een baan als agrarische arbeider accepteren, maar dat zij zodra zij klaar zijn met hun studie niet meer geïnteresseerd zijn om te werken in dit beroep. Wat betreft de bruto uitstroom zien we dat deze voor de jongere cohorten eveneens vrij hoog zijn. Voor de vrouwen daarentegen zien we dat de instroom hoog is voor de cohorten vanaf de leeftijd van 20 jaar tot de leeftijd van 44 jaar, terwijl de bruto uitstroom daalt met de leeftijd.

De figuren met de netto stromen laten voor het jongste cohort van de mannelijke agrarische arbeiders zien dat er sprake is van een netto instroom en dat voor de oudere cohorten een netto uitstroom wordt gemeten. Dit komt waarschijnlijk doordat studenten en scholieren na het behalen van een diploma een baan zoeken in de richting van hun studie. Voor de oudste twee cohorten wordt eveneens een forse netto uitstroom gemeten. Net zoals bij de monteurs en de bouwvakkers wordt de 'vroege' uitstroom hier vermoedelijk veroorzaakt door vervroegde pensionering. Door de fysieke zwaarte van hun beroep zullen agrarische arbeiders mogelijk iets eerder met pensioen willen dan werkenden in andere beroepen. Voor de vrouwen is de netto stroom moeilijker te verklaren. Voor de cohorten tussen de 25 jaar en de 44 jaar bestaat er een netto instroom. Echter, net zoals bij de mannen vinden wij echter een grote netto uitstroom voor de oudste twee cohorten.

Bij de artsen zien we dat terug dat voor de beroepsuitoefening een kwalificatie op universitair niveau vereist is. Daardoor zijn er nauwelijks artsen tussen de 15 en 19 jaar oud. Verder zijn er geen grote afwijkingen zichtbaar van het geijkte patroon. Voor zowel mannen als vrouwen vinden we dat de instroom het hoogst is voor de jongste cohorten en dat de uitstroom het hoogst is onder de jonge en oudere cohorten. Voor de cohorten tot 34 jaar is er sprake van een duidelijke netto instroom. Voor mannen is er sprake van een netto uitstroom voor de cohorten van 50 jaar of ouder. Voor de vrouwen valt al iets eerder een netto uitstroom waar te nemen (vanaf de leeftijd van 45 jaar). 
Figuur 3.7

Bruto instroom, uitstroom en netto stroom voor Agrarische arbeiders
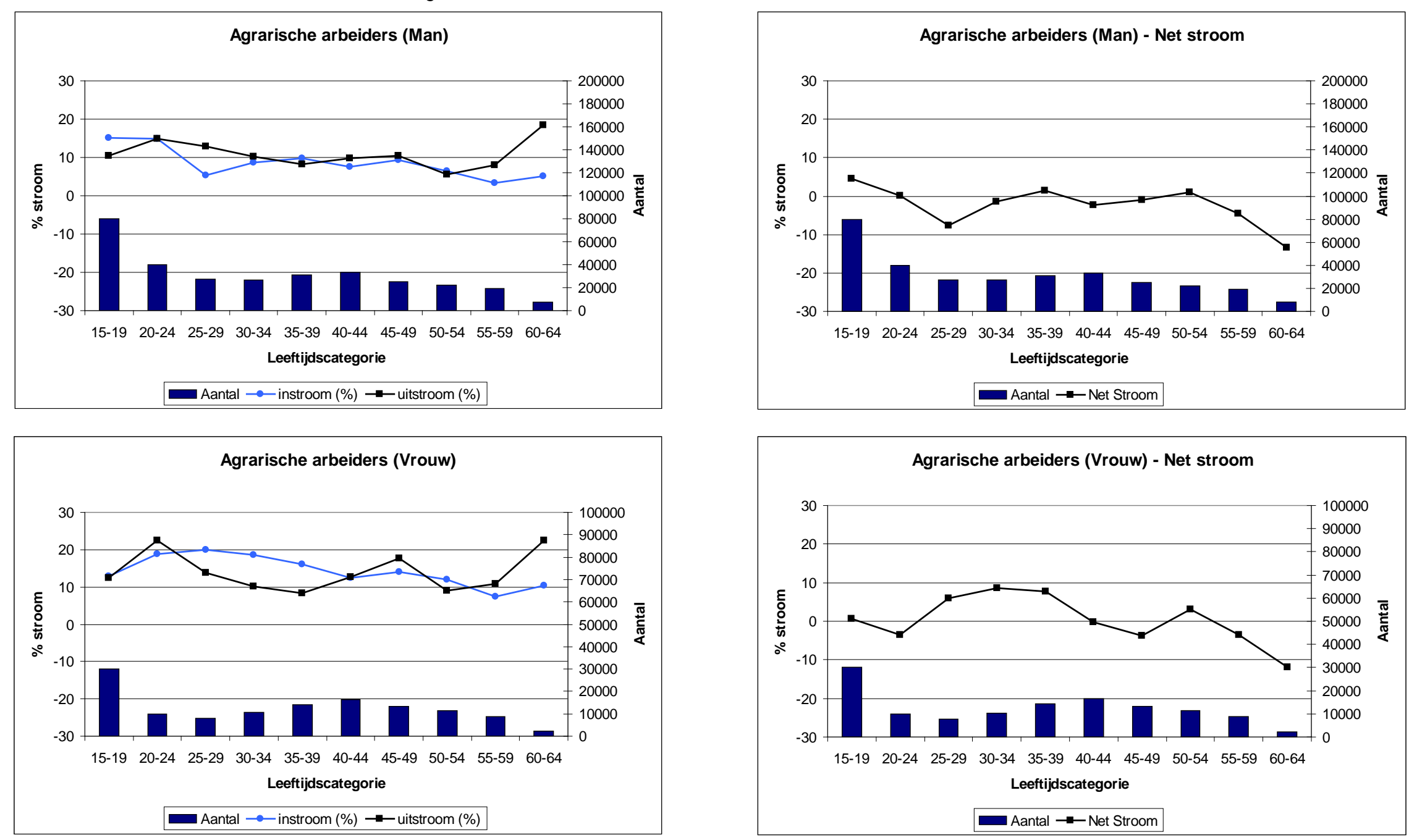
Figuur 3.8

Bruto instroom, uitstroom en netto stroom voor Artsen
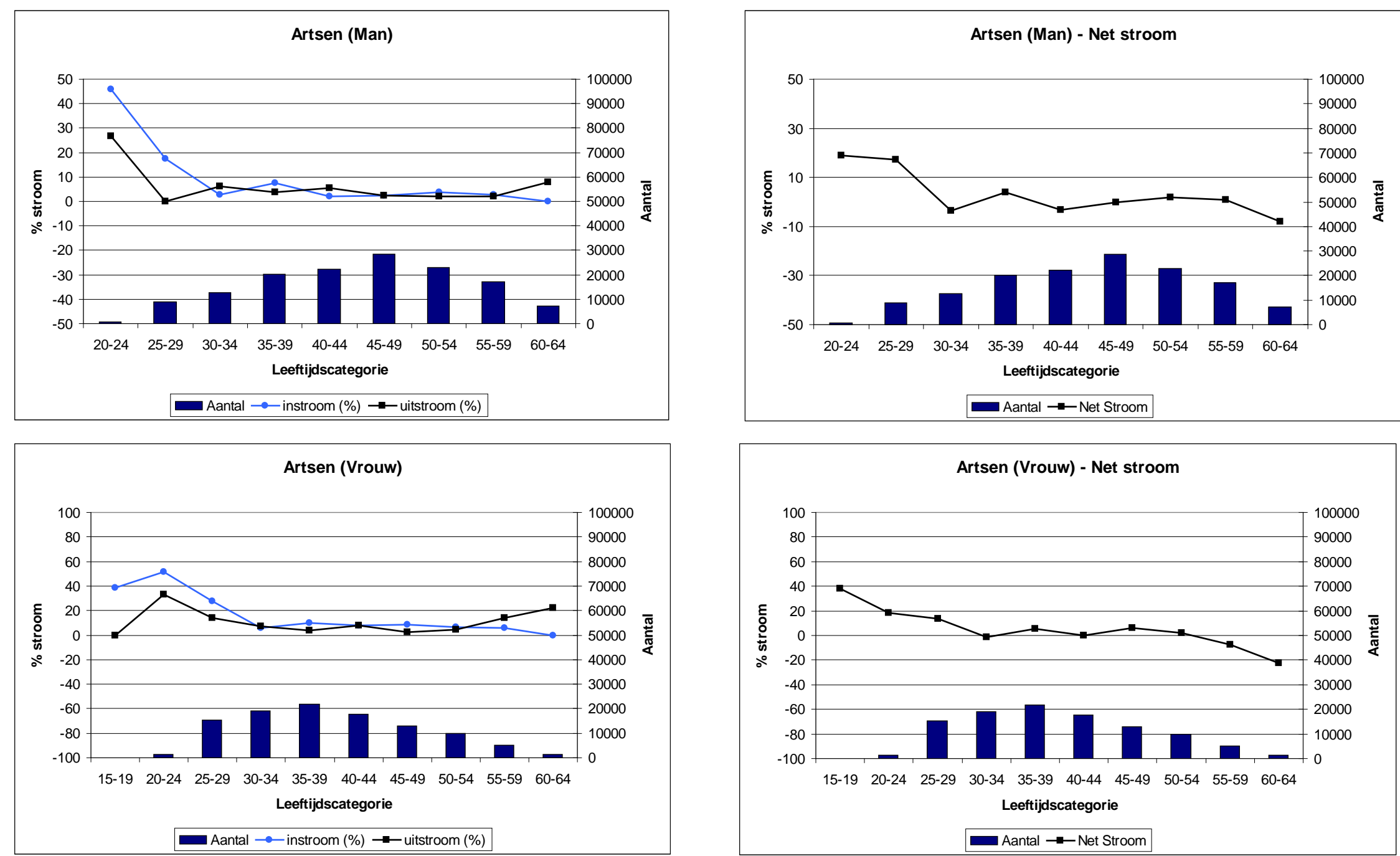


\section{Conclusie}

Het Researchcentrum voor Onderwijs en Arbeidsmarkt (ROA) maakt in het kader van het Arbeidsmarktinformatiesysteem (AIS) iedere twee jaar middellangetermijnprognoses naar opleiding en beroep. In deze studie is verkend in hoeverre het mogelijk is om een specifiek onderdeel van het prognosemodel, namelijk de vervangingsvraagmethodiek, verder te verbeteren. In het verleden waren paneldata over de beroepenmobiliteit niet beschikbaar, waardoor voor het bepalen van de vervangingsvraag een model is ontwikkeld dat nauw aansluit bij de in demografische analyses vaker gebruikte cohortcomponentenmethode. Sinds kort beschikt het ROA echter over paneldata vanuit de Enquête Beroepsbevolking (EBB) van het CBS, waaruit op een directe manier mobiliteitstromen op de arbeidsmarkt kunnen worden afgeleid. Deze studie gaat om de vraag in hoeverre de gegevens uit het EBB-panel gebruikt kunnen worden om de vervangingsvraagmethodiek te verbeteren. Daartoe richtte dit werkdocument zich op twee relevante vraagstukken: 1 ) de plausibiliteit van de EBB-paneldata en de 2) relatie tussen netto en bruto stromen en de mogelijke implementatie van deze stromen in de methodiek. Wat betreft de plausibiliteit zijn in dit rapport de analyses van de beroepenmobiliteit Bierings et al. (2009) verder uitgebreid door deze uit te splitsen naar cohorten zodat een beter beeld kan worden verkregen van de bruikbaarheid van de EBB-panelgegevens voor de vervangingsvraagprognoses. Zowel netto als bruto stromen werden gepresenteerd.

Het gebruik van het EBB-panel voor de vervangingsvraagprognoses heeft duidelijke voordelen boven de cohortcomponentenmethode die tot nu toe is gebruikt. Een belangrijk nadeel van de cohortcomponentenmethode is dat deze gebaseerd is op (minimaal) twee standcijfers waardoor de kans aanwezig is dat de steekproefonzekerheid een effect heeft op de mobiliteitsstromen en de uitstroomcijfers. Bij gebruik van de panelgegevens van het EBB heeft de steekproefonzekerheid daarentegen geen effect op de netto in- en uitstroom omdat de stromen worden bepaald op basis van één steekproeftrekking.

Uit deze studie kan worden geconcludeerd dat de bruto en netto stromen op basis van het EBB-panel plausibel blijven ongeacht de opsplitsing naar cohort en geslacht. De analyses in hoofdstuk 3 laten zien dat de bruto in- en uitstroom doorgaans hoger zijn voor jongere cohorten, wat vervolgens resulteert in een netto instroom. Volgens verwachting wordt voor de oudste cohorten een netto uitstroom gevonden die het gevolg is van de (vervroegde) uittreding van werknemers als gevolg van pensionering en het gebruik van arbeidsongeschiktheidsregelingen.

Deze studie biedt hieronder een overzicht van enkele punten waarvoor bij de verdere ontwikkeling van de vervangingsvraagmethodiek aandacht dient te worden besteed:

- In eerste instantie dienen uitstroomcoëfficiënten op basis van netto stromen te worden geschat. Het implementeren van bruto stromen impliceert dat ook andere onderdelen van het prognosemodel (uitbreidingsvraag en instroommethodiek) zouden moeten worden aangepast. 
- Schattingen op basis van het EBB-panel dienen te worden gedaan inclusief een weegschema dat corrigeert voor de selectieve paneluitval.

- Daarnaast moet bij deze schattingen expliciet aandacht worden besteed aan de stabiliteit van de schattingen, voornamelijk voor de kleinere beroepsgroepen, en dienen de coëfficiënten te worden vergeleken met de coëfficiënten die op basis van de cohort componentenmethode zijn berekend.

- Tot slot is het van belang om eveneens uitstroomcoëfficiënten op basis van het EBB-panel te berekenen ten behoeve van de vervangingsvraag naar opleiding. Daarvoor kunnen in principe dezelfde methoden worden gebruikt als voor het bepalen van de vervangingsvraag naar beroep. Echter, doordat de meeste veranderingen van opleidingsniveau plaatsvinden in de jongste cohorten, is het de vraag in hoeverre stromen voor de oudere cohorten groot genoeg zijn.

Aangezien het gebruik van het EBB-panel voor de vervangingsvraagprognoses duidelijke voordelen heeft boven de cohortcomponentenmethode en de bruto en de afgeleide netto stromen plausibel zijn, loont het de moeite om de vervangingsvraagmethodiek aan te passen. De vervolgstap is om schattingen te maken van uitstroomcoëfficiënten op basis van het EBB-panel die vervolgens de coëfficiënten van cohortcomponentenmethode kunnen vervangen. Daarbij dient expliciet rekening te worden gehouden met de bovengenoemde aandachtspunten.

\section{Literatuur}

Borghans, L., A. de Grip, E. Willems (1995), Herijking ROA Informatiesysteem OnderwijsArbeidsmarkt, ROA-R-1995/1, Maastricht.

Bierings, H., F. Cörvers, R. Montizaan, R. de Vries, Beroepenmobiliteit: Bruikbaarheid longitudinale gegevens Enquête Beroepsbevolking, ROA-TR-2009/2, Maastricht.

Centraal Planbureau (2004), Arbeidsaanbod in de lange-termijnscenario's voor Nederland, CPBDocument 71, Den Haag.

Clements, M.P. (1995), Rationality and the role of judgement in macroeconomic forecasting, Economic Journal, Vol. 105, pp. 410-420.

Cörvers F., Dupuy, A., Dijksman, S., Kriechel, B., and R. Montizaan (2008), Methodiek arbeidsmarktprognoses en -indicatoren 2007-2012, ROA-TR-2008/2, Maastricht.

Cörvers, F., B. Kriechel, R. Montizaan (2006), Scenario-analyse van de vervangingsvraag, ROA-W2006/1, Maastricht.

Montizaan, R. (2009), Evaluatie vervangingsvraagprognoses naar opleiding en beroep, ROA-TR2009/1, Maastricht.

ROA (2009), De arbeidsmarkt naar opleiding en beroep tot 2014, ROA-R-2009/5, Maastricht.

Shah, C., G. Burke (2001), Occupational Replacement Demand in Australia, International Journal of Manpower, Vol. 22, pp. 648-663.

Shyrock, H.S., J.S. Siegel (1980), The Methods and Materials of Demography, U.S.Bureau of the Census, U.S. Printing Office, Fourth Printing (rev.), Washington D.C.

Willems, E.J.T.A., A. de Grip (1993), Forecasting Replacement Demand by Occupation and Education, International Journal of Forecasting, Vol. 9, pp. 173-185.

Willems, E. (1996), Manpower Forecasting and Modelling Replacement Demand: an Overview, ROAW-1996/4E, Maastricht. 


\section{Appendix A: Huidige methodiek vervangingsvraag}

In deze appendix wordt de huidige methodiek besproken die wordt gehanteerd voor de prognoses van de vervangingsvraag voor individuele beroepsgroepen. De methodiek bestaat uit een model dat nauw aansluit bij de in demografische analyses vaker gebruikte cohort componentenmethode. De cohort componentenmethode baseert de berekening van de zogenaamde 'cohort change rates' op het aantal personen in hetzelfde geboortecohort die werkzaam zijn in twee verschillende tijdsperioden. Een cohort is hier een combinatie van geslacht en vijfjaarsleeftijdsklasse. ${ }^{4}$ Deze methode maakt gebruik van standcijfers over de geslachts- en leeftijdsopbouw van de beroepsbeoefenaren over een aantal jaren. ${ }^{5}$ Door van jaar op jaar een vergelijking te maken van de demografische opbouw in een bepaalde beroepsgroep of een bepaald opleidingstype, wordt een beeld verkregen van de (netto) inof uitstroom voor de desbetreffende beroepsgroep of het desbetreffende opleidingstype. Op dit model zal hier kort worden ingegaan (zie voor een verdere toelichting Willems, 1999).

Kernpunt bij de methodiek voor de bepaling van de vervangingsvraag is de afleiding van de netto in- en uitstroomratio's. Deze ratio's weerspiegelen de relatieve toe- of afname van het aantal werkenden in een beroepsgroep ${ }^{6}$ van een bepaald geboortecohort gedurende een bepaalde periode. In symbolen kunnen de 'cohort change rates' worden weergegeven als: ${ }^{7}$

$$
\dot{F}_{b x}^{t-1}=\frac{W_{b x+1}^{t}-W_{b x}^{t-1}}{W_{b x}^{t-1}}
$$

waarbij:

$\dot{F}_{b x}^{t-1}=$ netto in- of uitstroomratio van de werkenden in beroep $b$ met leeftijdklasse $x$ op tijdstip $t-1$, gedurende de periode $(t-1, t)$;

$W_{b x}^{t}=$ aantal werkenden in beroep $b$ in leeftijdsklasse $x$ op tijdstip $t$.

Indien $\dot{F}_{b x}^{t-1}>0$ dan is er sprake van netto instroom voor leeftijdscohort $x$ van beroep $b$ en als $\dot{F}_{b x}^{t-1}<0$ dan is er sprake van netto uitstroom. Er wordt dus met behulp van de cohort change rate de netto uitstroom, het saldo van uit- en in-stroom, in het verleden per beroepsgroep bepaald. De vervangingsvraag die wordt opgevuld door (her-)intredende personen van hetzelfde cohort (combinatie van geslacht én leeftijdsklasse) kan niet uit de beschikbare data worden afgeleid en wordt derhalve ook niet expliciet bij de bepaling van de

4. Zie voor een verdere toelichting Shryock en Siegel (1980).

5. Bij het opstellen van de prognoses voor de periode tot 2010 is gebruik gemaakt van naar geslacht en leeftijdsklasse verbijzonderde gegevens over het aantal werkenden per beroepsgroep en opleidingstype voor de periode 1996-2006.

6. De methodiek is hier uitgewerkt voor de vervangingsvraag per beroepsgroep. De vervangingsvraag per opleidingstype wordt op vrijwel analoge wijze bepaald.

7. Daarnaast zijn de ratio's verbijzonderd naar geslacht. Omwille van de overzichtelijkheid van de notatie is de geslachtsindex weggelaten. 
vervangingsvraag meegenomen. Dit houdt in dat wordt aangenomen dat een meer dan normaal (op basis van het verleden) geacht aantal herintreders in de wachtrij voor nieuwe banen achteraan moet sluiten bij de nieuw op de markt komende schoolverlaters (zie ook Borghans, De Grip en Willems, 1995).

Vervolgens wordt er gebruik gemaakt van een 'fixed-effect-model', waarbij de netto in- of uitstroomratio's worden verklaard op basis van de beroepsspecifieke afwijkingen per geslacht en leeftijdsklasse van de gemiddelde in- of uitstroompatronen uit de totale werkzame bevolking. Dit houdt in dat als een geschatte uitstroomcoëfficiënt voor een bepaalde beroepsklasse of opleidingstype sterk afwijkt, de geschatte parameter die de afwijking van het gemiddelde aangeeft waarschijnlijk significant zal zijn. Een dergelijke aanpak garandeert dat de som van de netto stromen over de beroepen overeenkomt met de totale netto in- of uitstroom.

In formulevorm:

$$
\begin{aligned}
\dot{F}_{b}= & \dot{F}+\sum_{x} \beta_{b x} D_{x} \\
\dot{F}_{b}= & \text { vector van netto in- of uitstroomratio's voor beroep } b, \text { met waarnemingen per } \\
& \text { geslacht, leeftijdsklasse en jaar; } \\
\dot{F}= & \text { idem, maar dan voor de gehele werkzame bevolking; } \\
D_{x}= & \text { matrix met dummy-variabelen; waarden zijn gelijk aan } 1 \text { voor cohort x en } 0 \text { elders; } \\
\beta_{b x}= & \text { random parameters. }
\end{aligned}
$$

De vergelijking laat zien dat de stromen van de arbeidsmarkt voor een bepaalde beroepsgroep per leeftijdscohort gelijk zijn aan de gemiddelde stroom van de arbeidsmarkt van dat leeftijdscohort, afgezien van beroepsspecifieke afwijkingen die kunnen verschillen per leeftijdsklasse.

Onder de veronderstelling dat de niet-werkzame beroepsbevolking in de prognoseperiode gelijk blijft (de zgn. conjunctuurcorrectie, zie hieronder), wordt een voorspelling gekregen van de toekomstige uitstroom uit de werkzame bevolking. De schattingsresultaten van vergelijking dienen als basis voor een prognose van de toekomstige netto in- en uitstroomratio's. Deze uitstroomcoëfficiënten worden met behulp van de door het CPB opgestelde prognoses van de (bruto) participatiegraad in het zogenaamde Transatlantic Market (TM) scenario van het Centraal Planbureau (CPB, 2004) geprojecteerd op de populatie in het basisjaar om een prognose te kunnen maken van de uitstroom in de komende jaren. $^{8}$ Deze prognose is dus voor alle cohorten van de beroepsbevolking

8. Zie Cörvers, Kriechel en Montizaan (2006) voor een scenario-analyse van de vervangingsvraag. Uit deze studie blijkt tevens de beperkte gevoeligheid voor afwijkingen van de toekomstige ontwikkeling van de participatiegraad ten opzichte van het gehanteerde TM-scenario ('Transatlantic Market'). In de laatste prognosestudie (ROA, 2009) zijn overigens nieuwe CPB-prognoses van de participatiecijfers gebruikt. 
gecorrigeerd voor de verwachte verandering in de arbeidsparticipatie. Naast deze participatiecorrectie vindt ook een vergelijkbare correctie plaats voor de conjuncturele situatie in de analyseperiode. Beide correctiefactoren zijn voor alle beroepsklassen en opleidingstypen gelijk. Figuur A1 bevat een samenvattend overzicht van de methodiek van het opstellen van de prognoses voor de vervangingsvraag. ${ }^{9}$

De correctie voor de conjuncturele situatie is gelijk aan het verschil tussen de verandering in het totale aantal werkende personen en de verandering in de beroepsbevolking in de historische periode. Deze correctie compenseert de uitstroom van werkenden die werkloos zijn geraakt door conjuncturele fluctuaties in het werkgelegenheidsniveau. De correctie voor de verandering in de participatiegraad is het verschil tussen de groei in de beroepsbevolking in de historische periode en de voorspelperiode.

Als de correcties voor de conjunctuur en de participatiegraad gecombineerd worden dan levert dit de voorspelde toekomstige uitstroomratio per cohort op:

$$
\begin{aligned}
\dot{W}_{b x}^{t, m} & =\dot{W}_{b x}^{t, n}-\dot{W} P_{x}^{t, n}+\dot{L} F_{x}^{t, n}+\dot{L} F_{x}^{t, m}-\dot{L} F_{x}^{t, n} \\
& =\dot{W}_{b x}^{t, n}-\dot{W} P_{x}^{t, n}+\dot{L} F_{x}^{t, m}
\end{aligned}
$$

waarbij:

$\dot{W}_{b x}^{t, m}=\quad$ de verwachte gemiddelde jaarlijkse netto in- of uitstroomratio van werkenden in beroep $b$, in cohort $x$ op tijdstip $t$ gedurende de voorspelperiode $(t, t+m)$;

$\dot{W}_{b x}^{t, n}=\quad$ de verwachte gemiddelde jaarlijkse netto in- of uitstroomratio van werkenden in beroep $b$, in cohort $x$ op tijdstip $t$ - $n$ gedurende de periode $(t-n, t)$;

$\dot{W} P_{x}^{t, n}=$ de gemiddelde jaarlijkse groeiratio van het totale aantal werkende personen in cohort $x$ op tijdstip $t-n$ gedurende de periode $(t-n, t)$;

$\dot{L} F_{x}^{t, n}=\quad$ de gemiddelde jaarlijkse groeiratio van de beroepsbevolking in cohort $x$ op tijdstip $t$ - $n$ gedurende de periode $(t-n, t)$;

$\dot{L} F_{x}^{t, m}=\quad$ de verwachte gemiddelde jaarlijkse groeiratio van de beroepsbevolking in cohort $x$ op tijdstip t gedurende de voorspelperiode $(t, t+m)$.

9. Zie Shah en Burke (2001) voor een vergelijking van de methodiek van de vervangingsvraag naar beroep tussen Australië, de Verenigde Staten en Nederland. 
Figuur A1

Samenvattend overzicht van de methodiek van de vervangingsvraag (excl. specifieke aanpassingen en 'doorleerderscomponent')

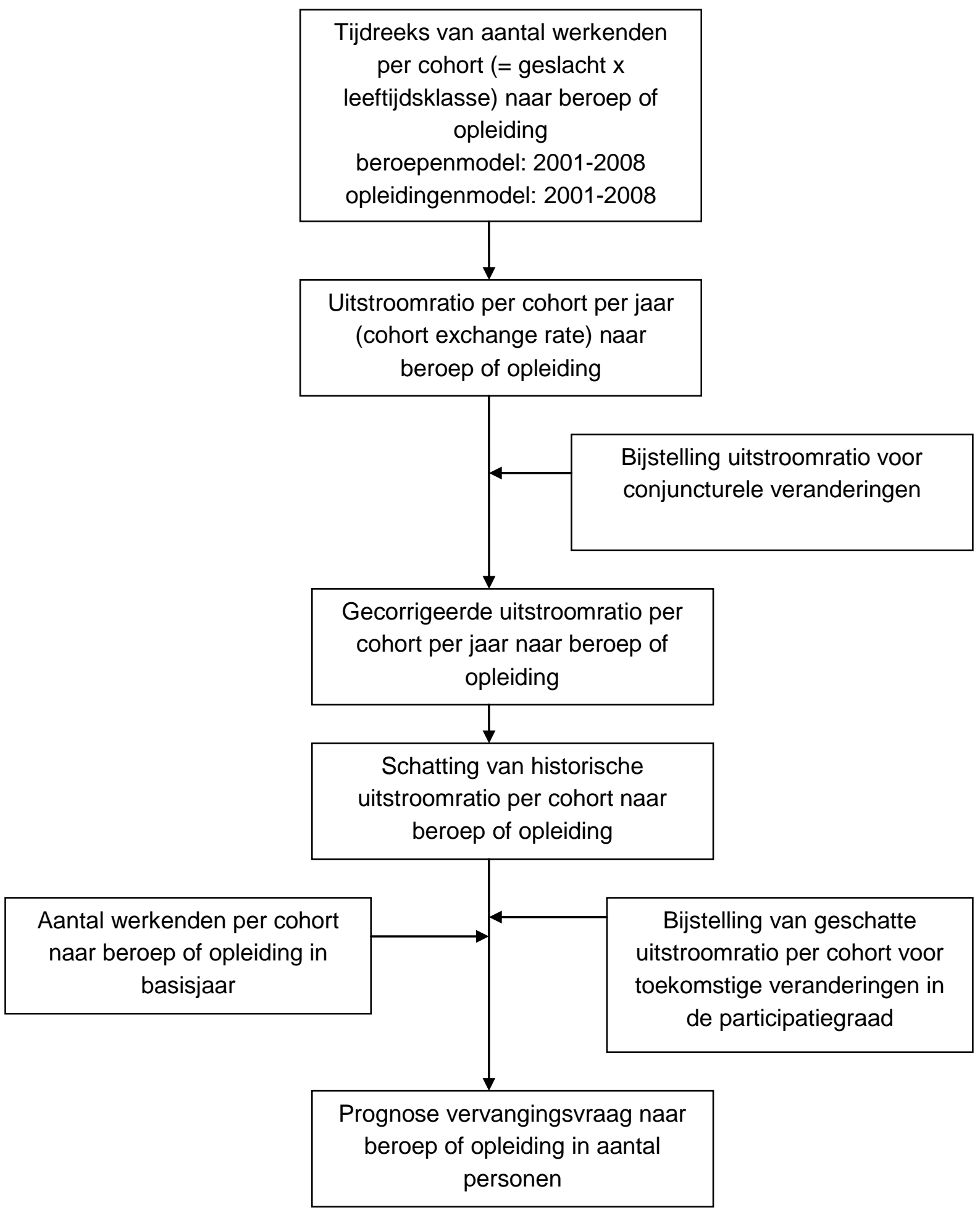


De toekomstige vervangingsvraag wordt in feite op dezelfde manier bepaald als de vervangingsvraag in de historische periode. Dit houdt in dat voor beroepsgroepen met een verwachte stijging van de werkgelegenheid de vervangingsvraag gelijk is aan de netto uitstroom. De ontwikkeling van de werkgelegenheid per beroepsgroep wordt per geslacht afzonderlijk bekeken. Voor beroepsgroepen waarbij een daling van de werkgelegenheid in een bepaald jaar voor één van beide geslachten wordt verwacht, wordt de vervangingsvraag voor het betreffende jaar en geslacht op nul gesteld. 


\section{Appendix B: Figuren}
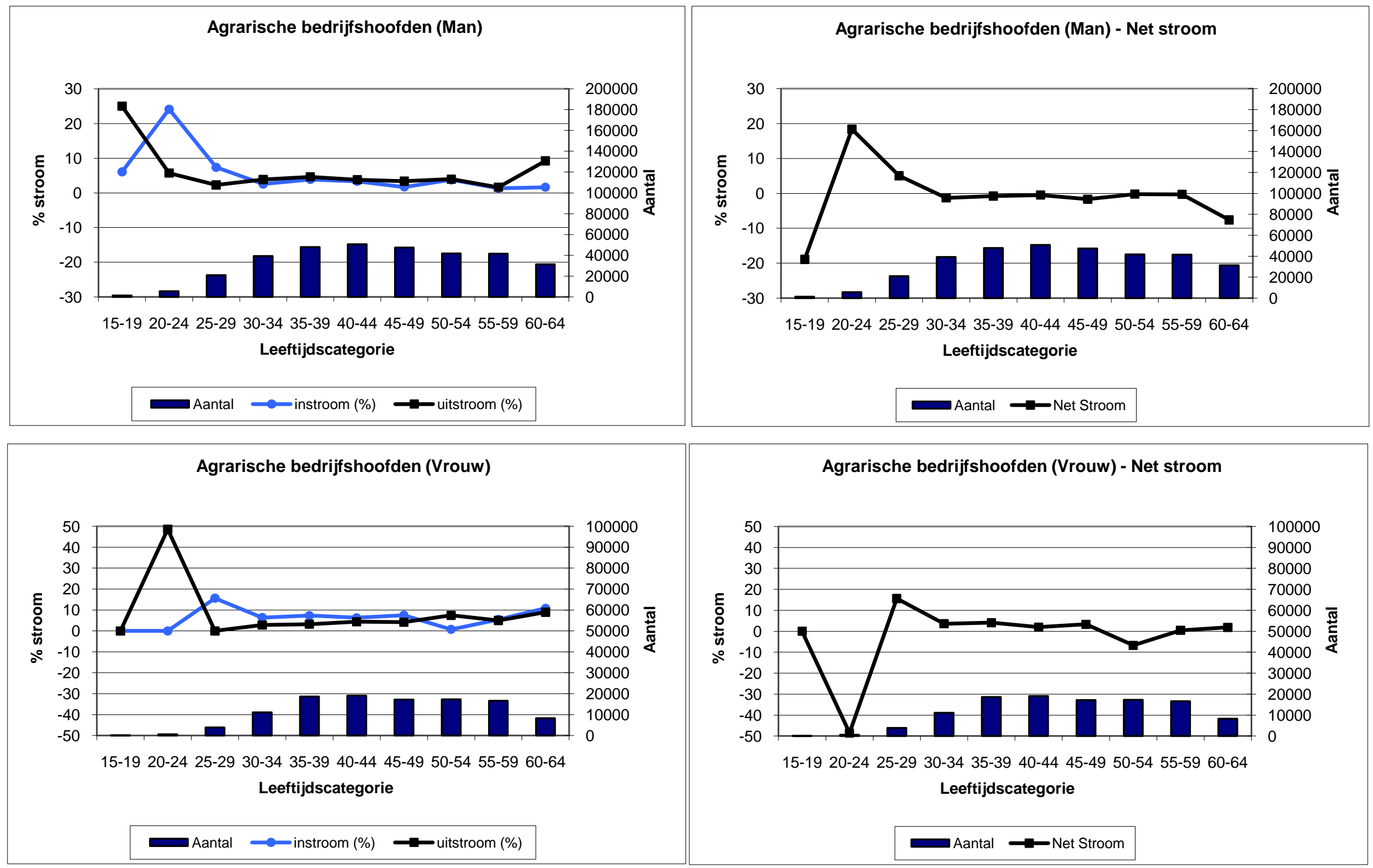

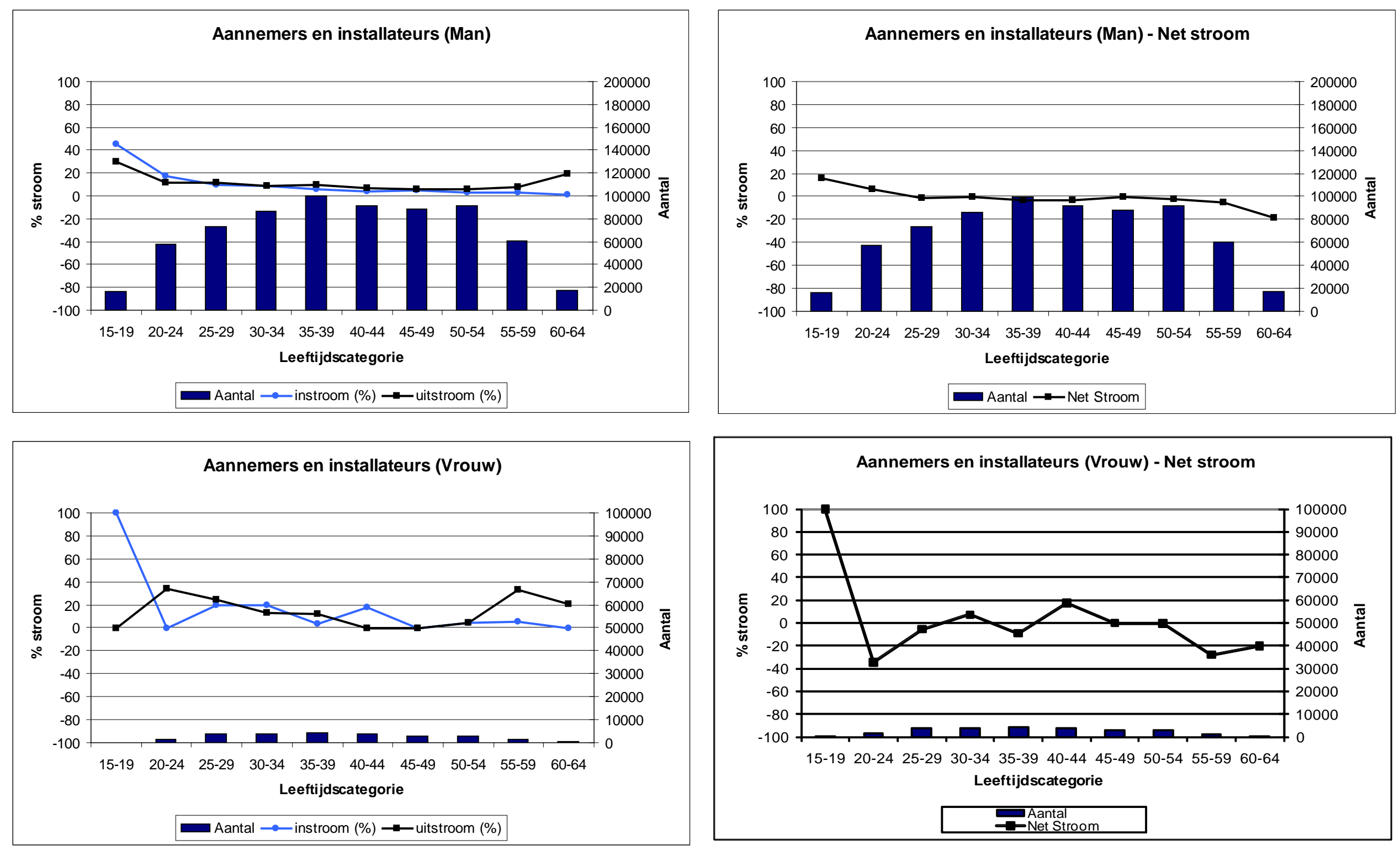

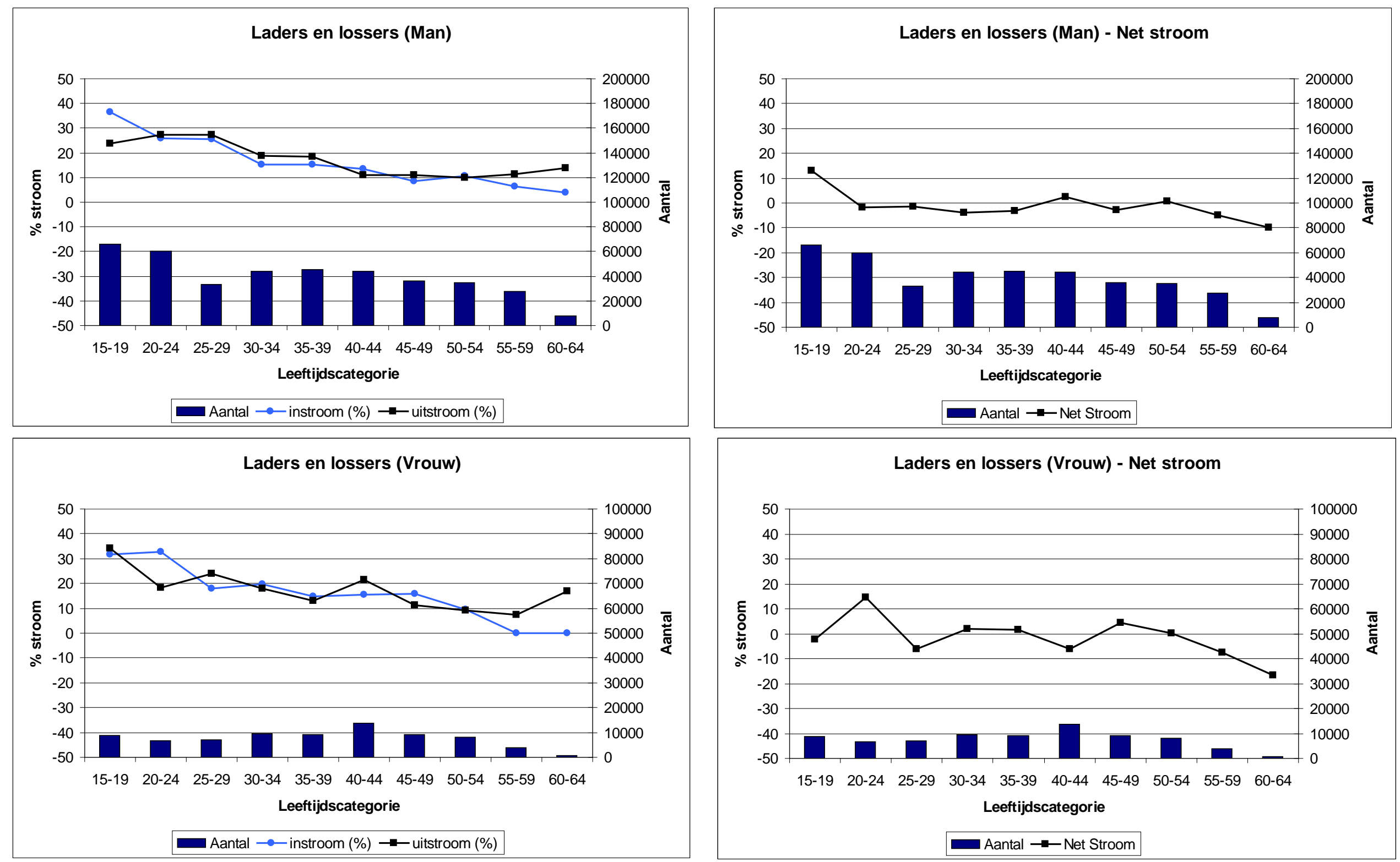

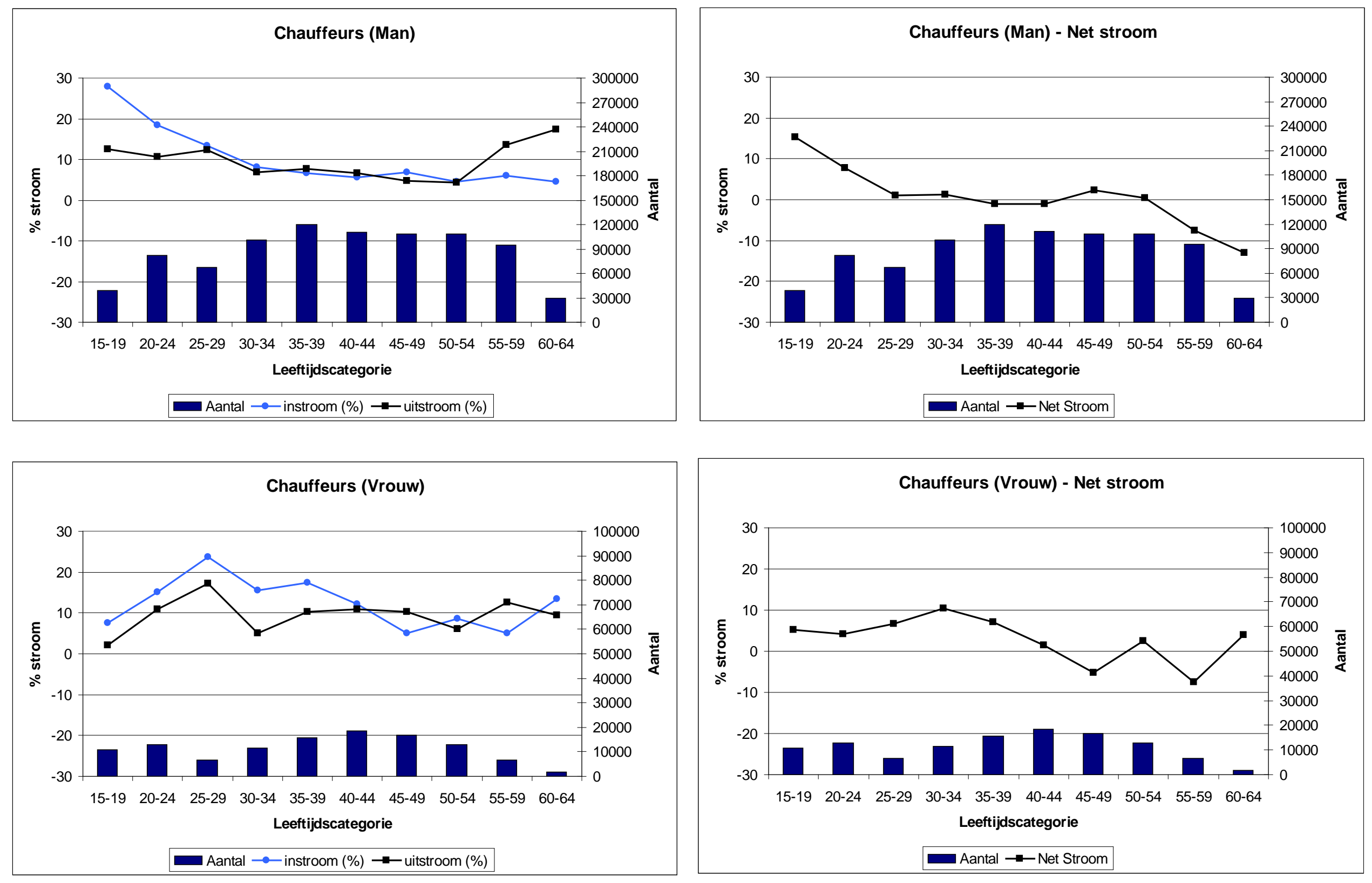

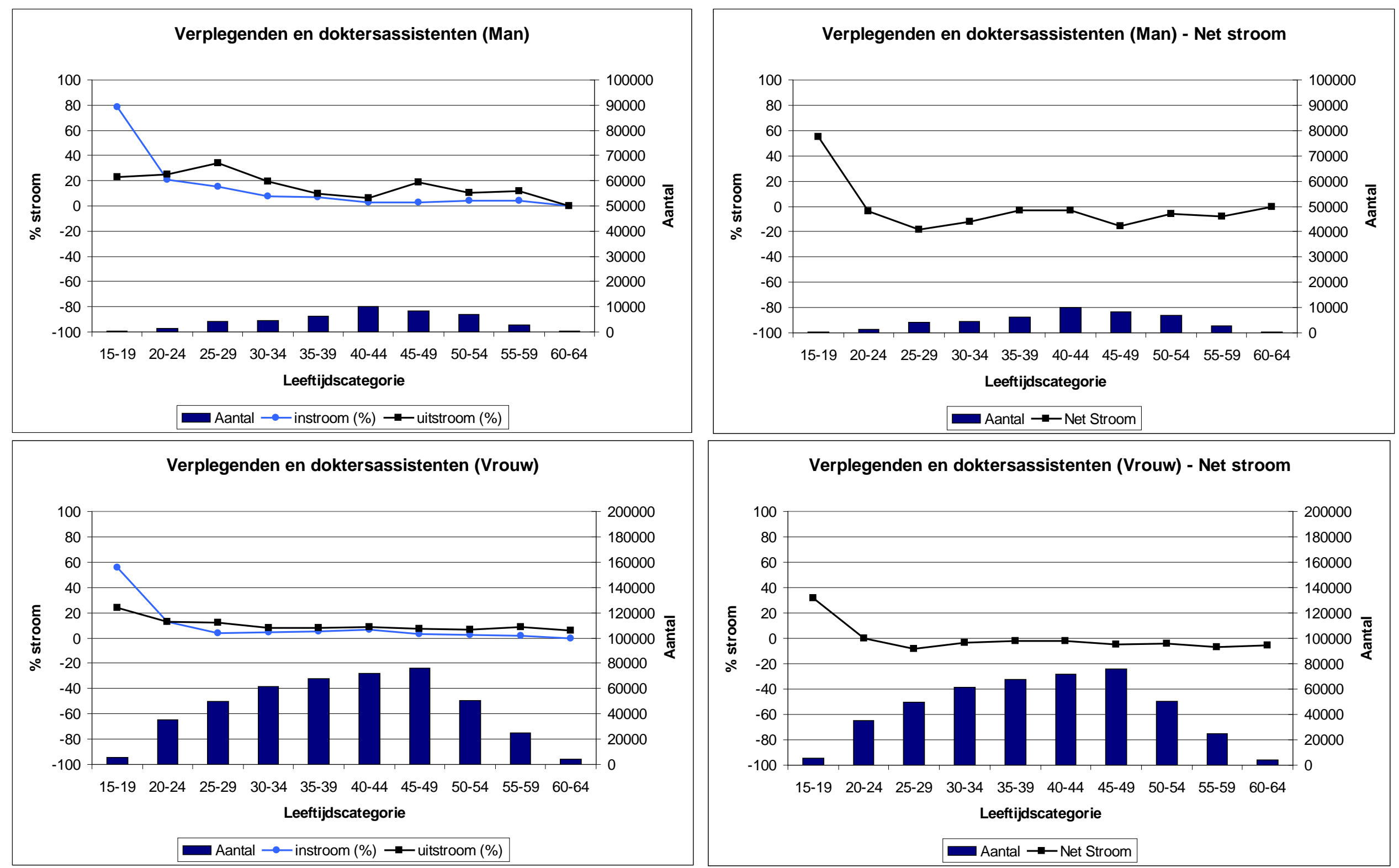

Verplegenden en doktersassistenten (Vrouw) - Net stroom

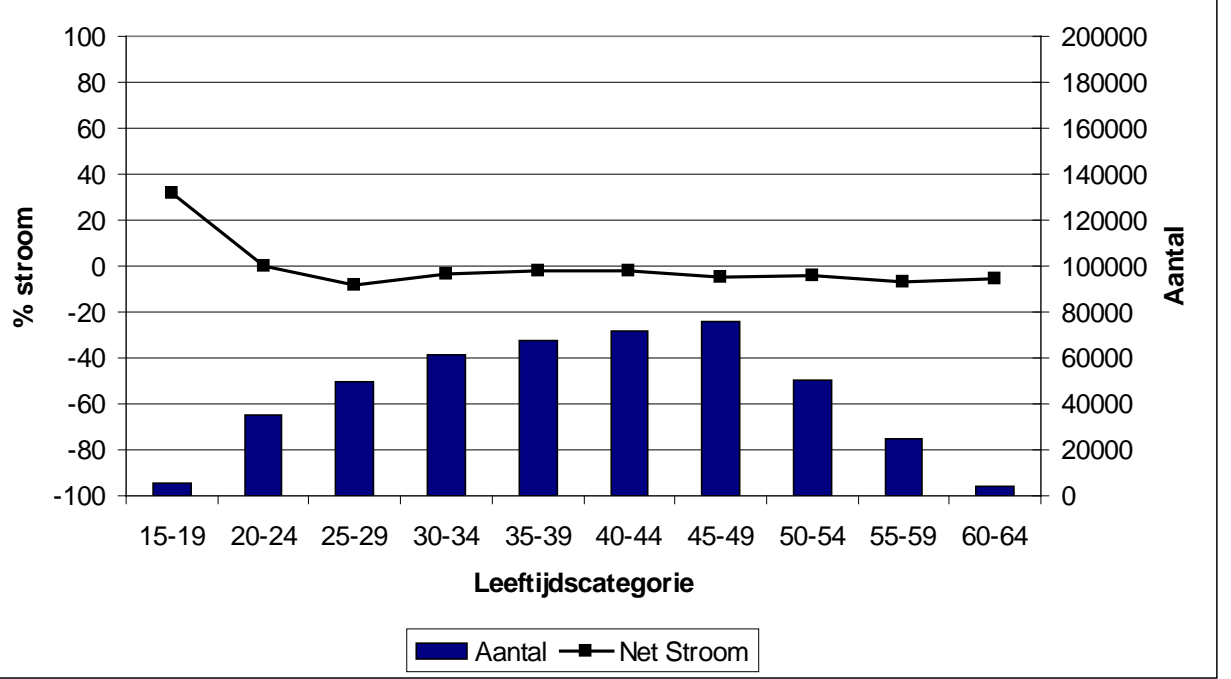



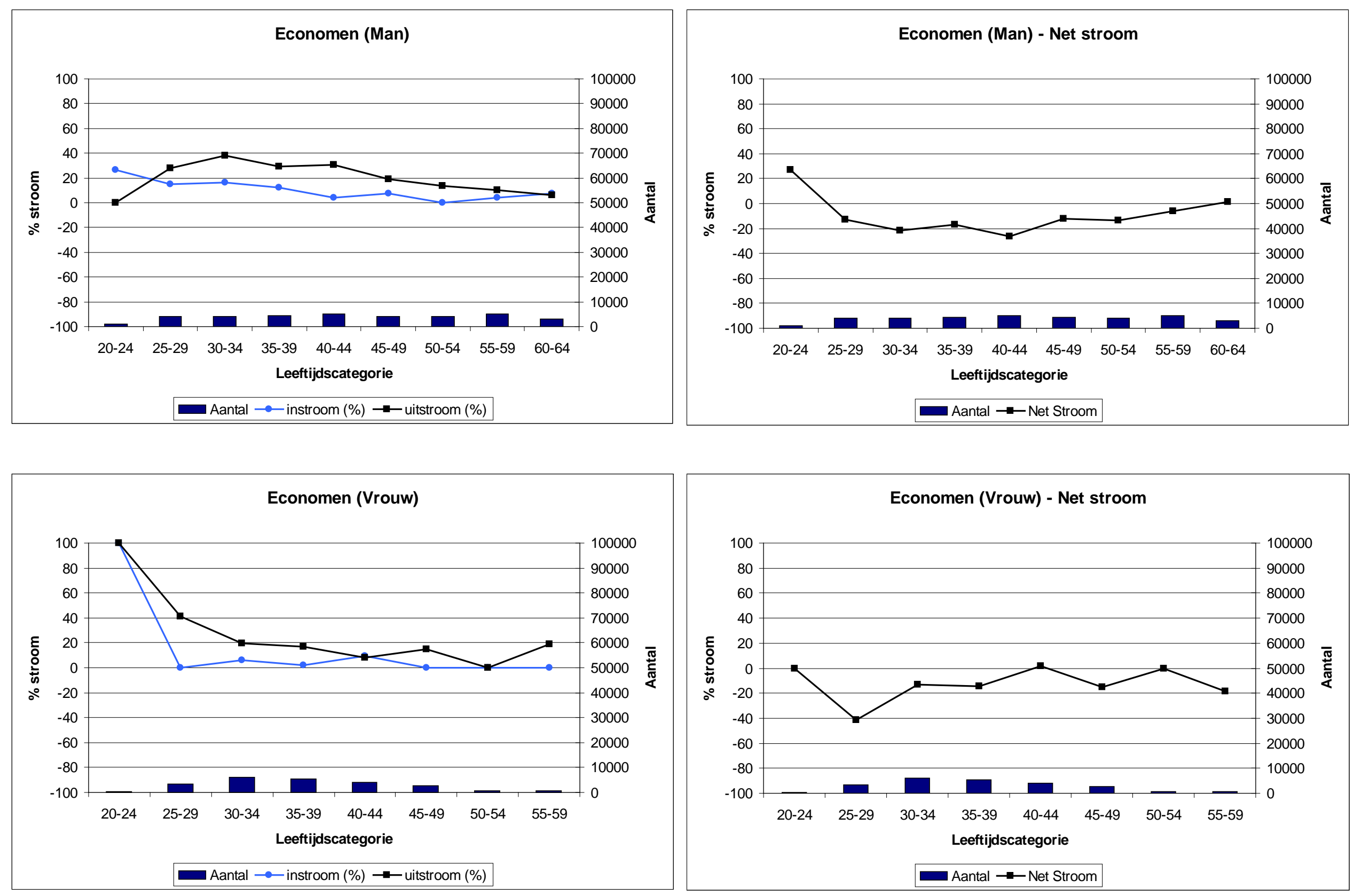

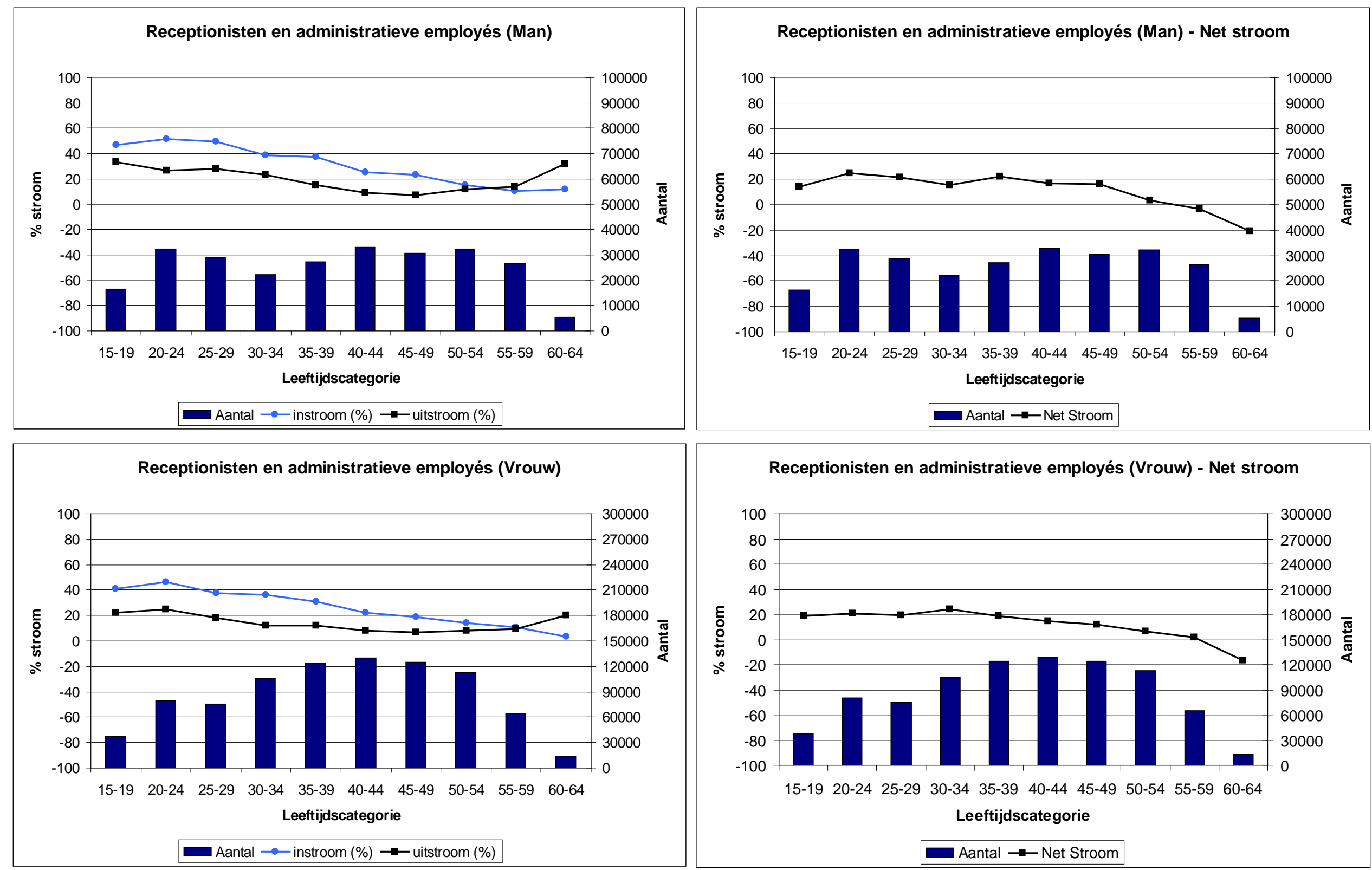

Receptionisten en administratieve employés (Vrouw) - Net stroom

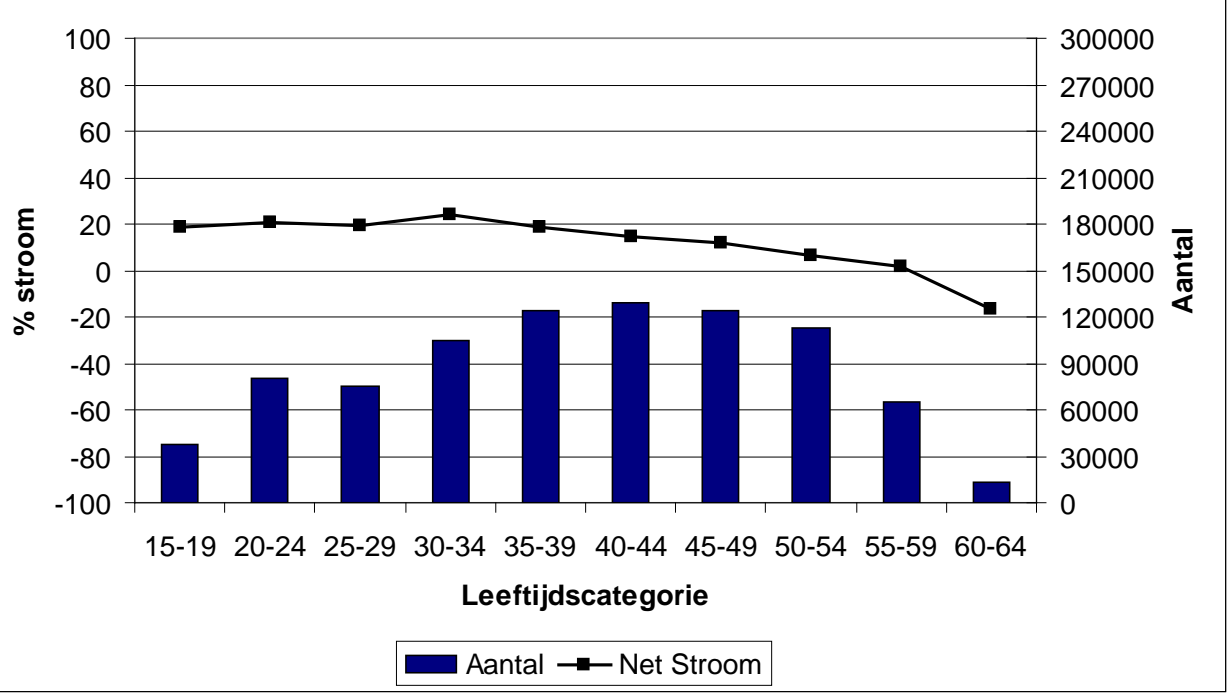



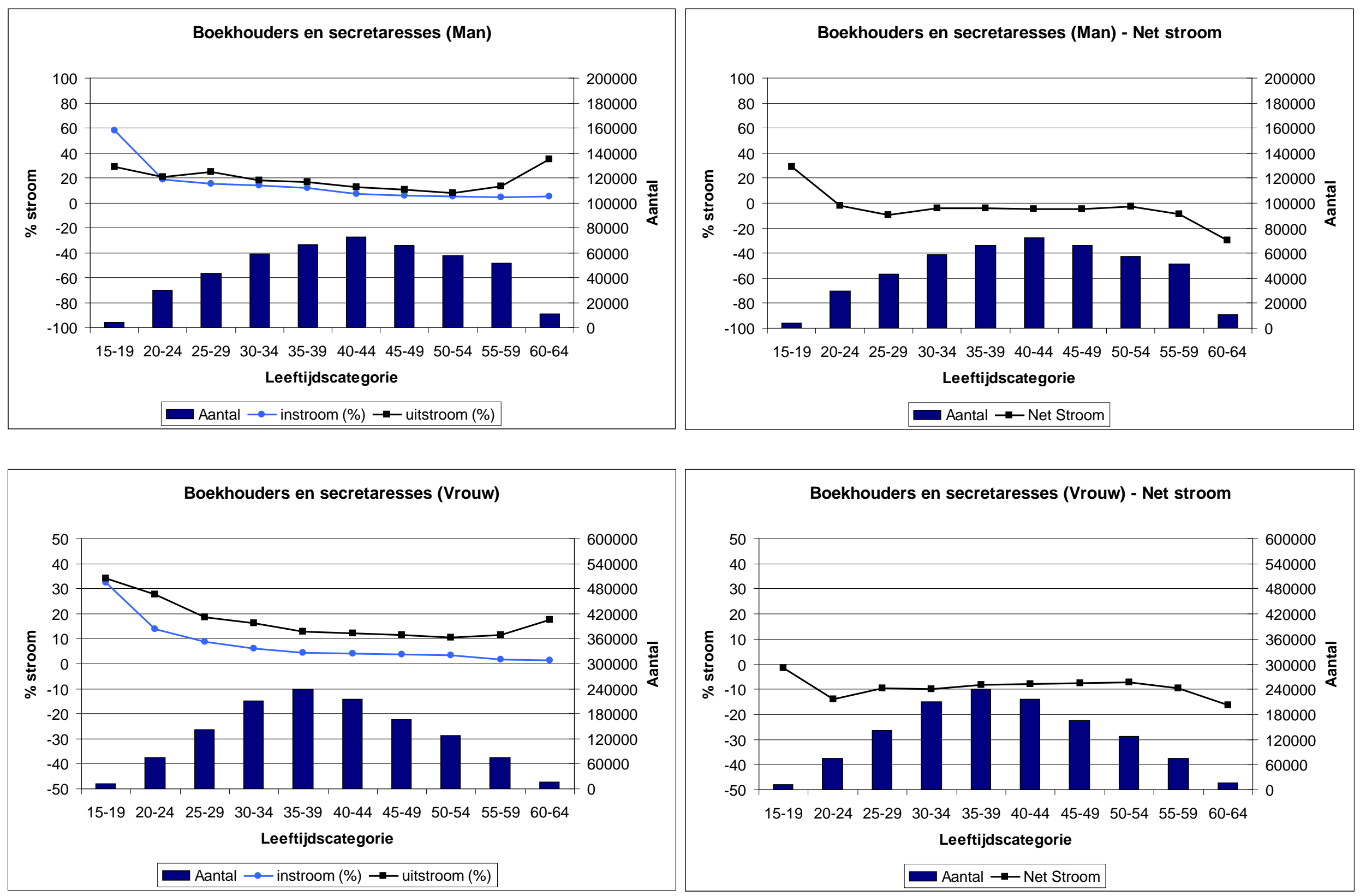

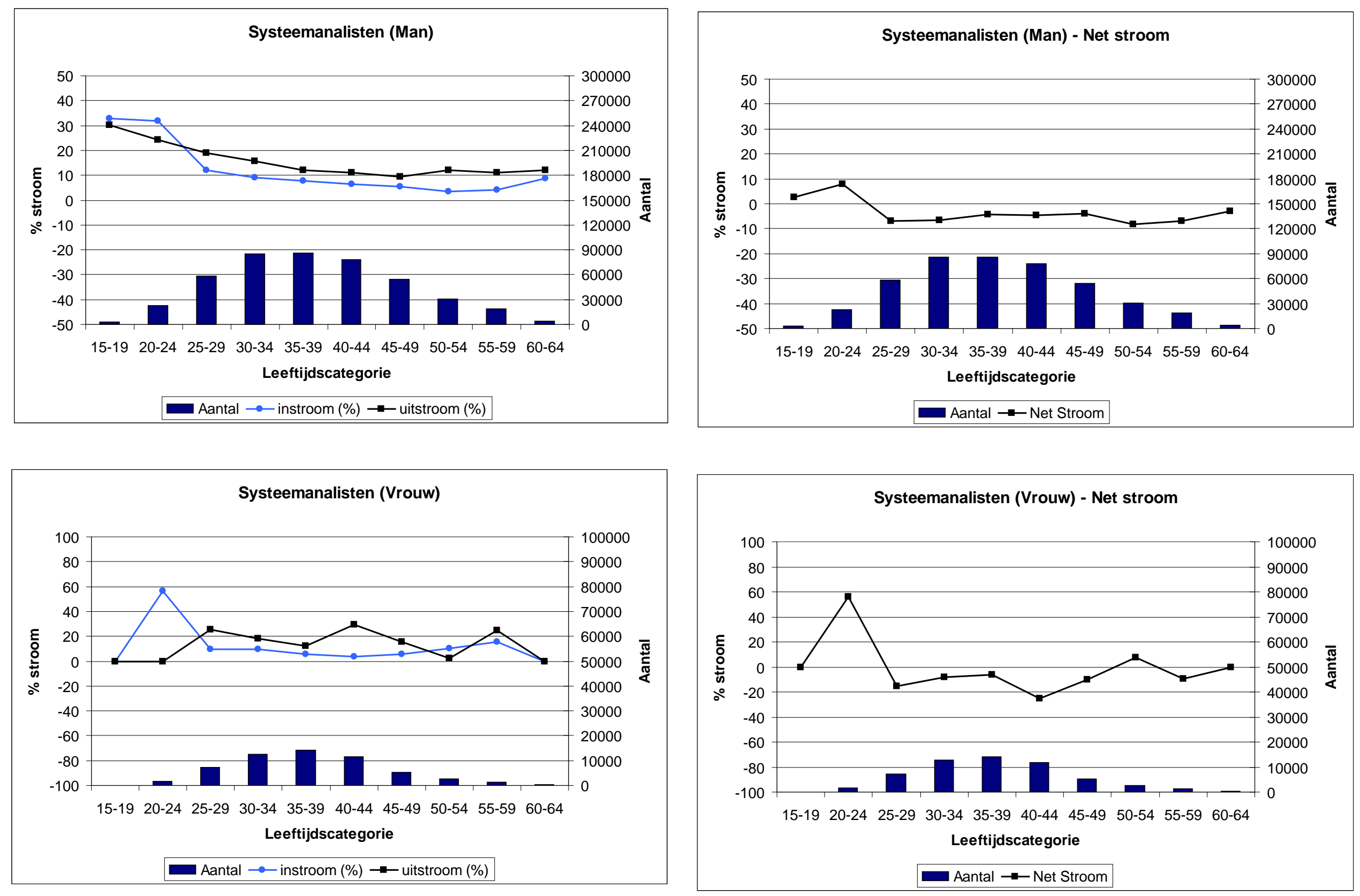

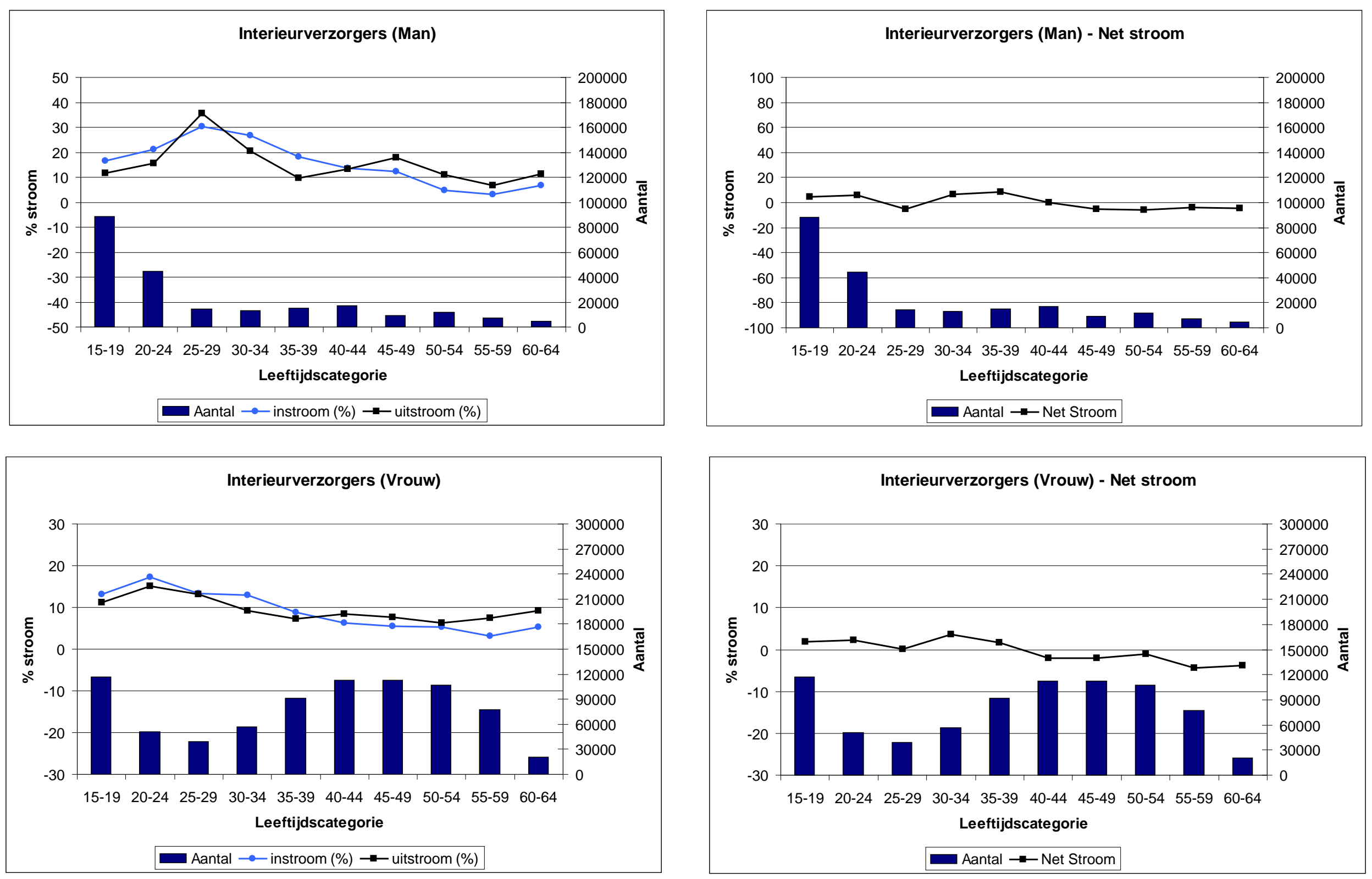

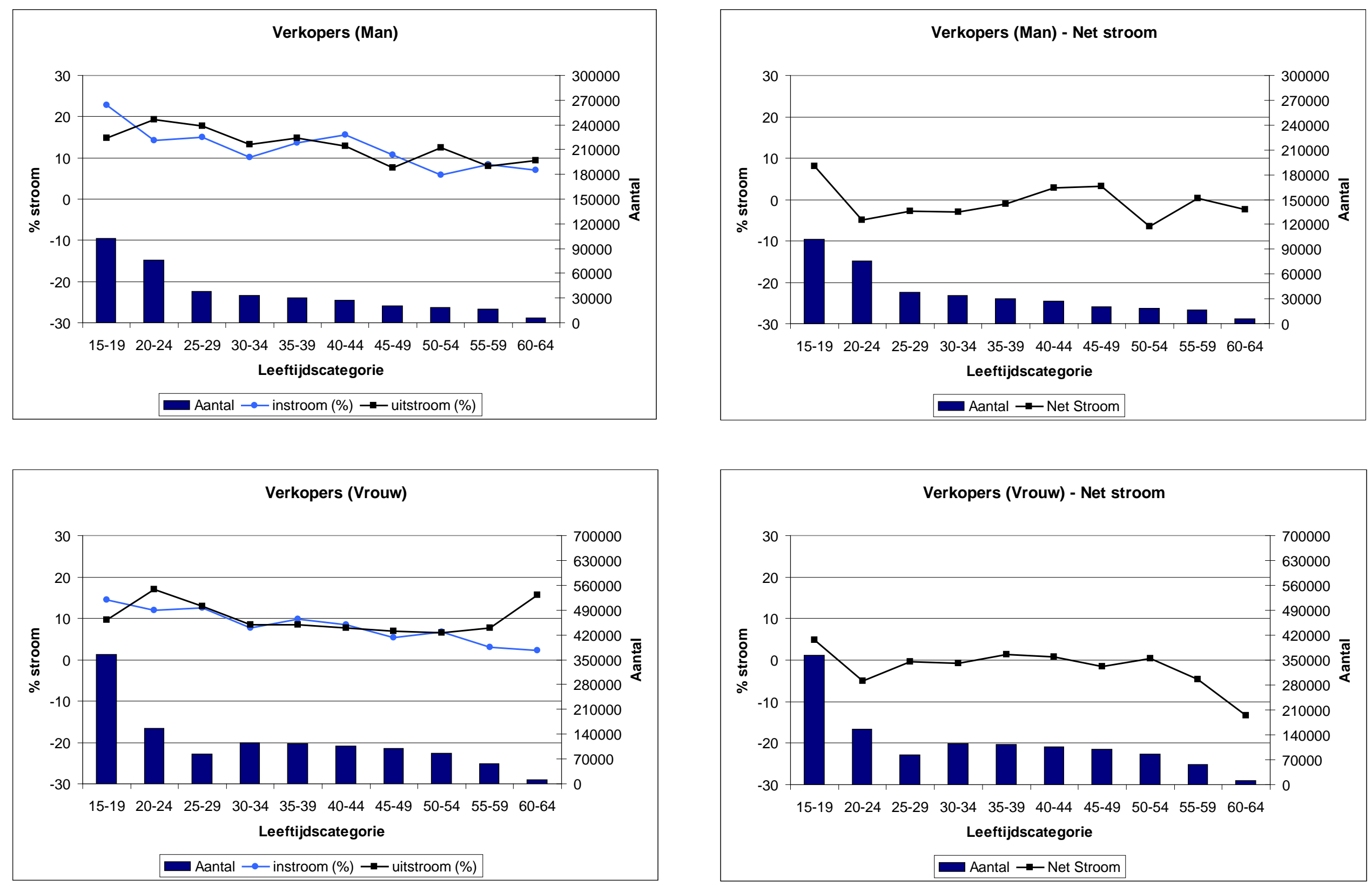

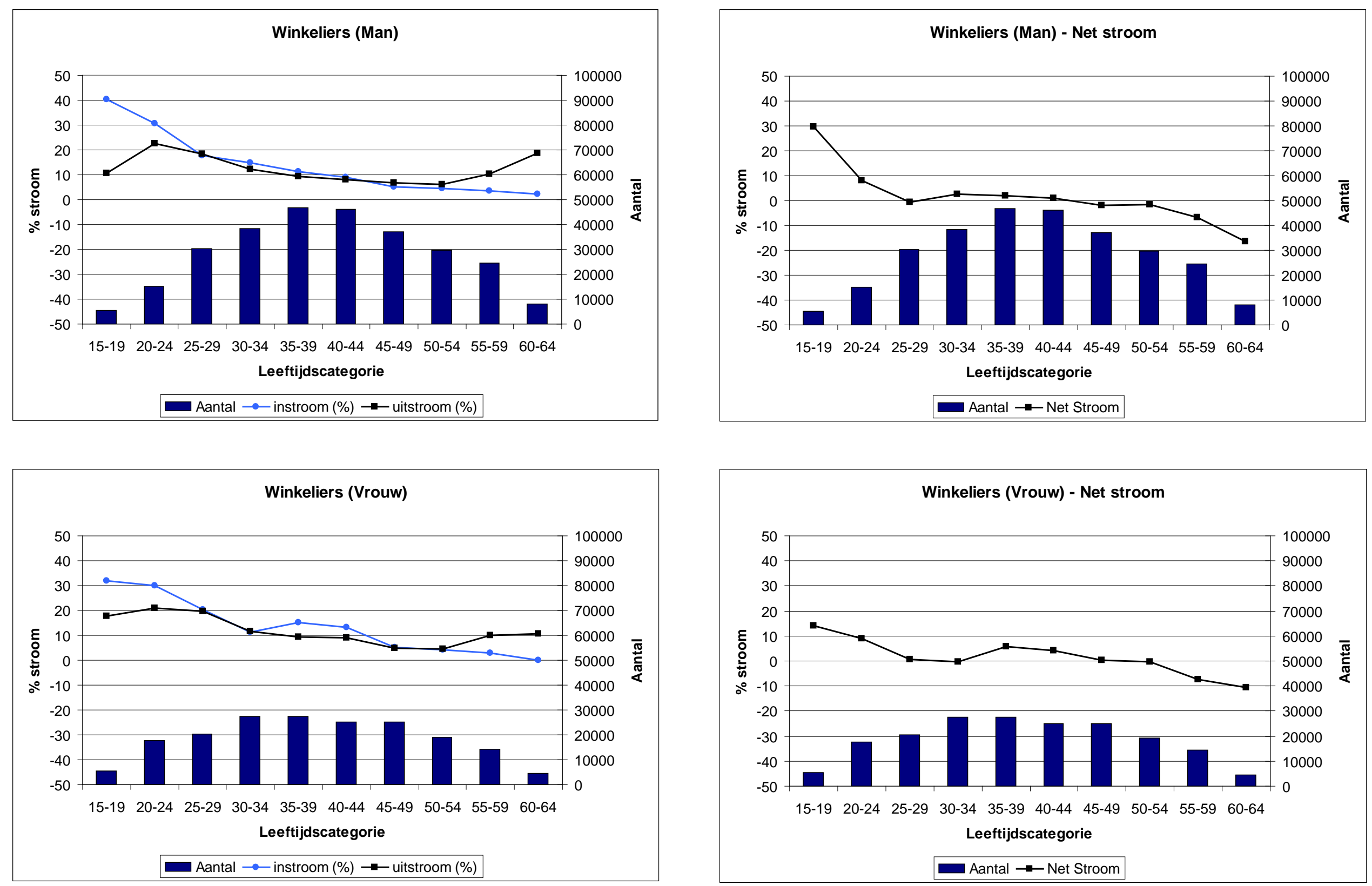

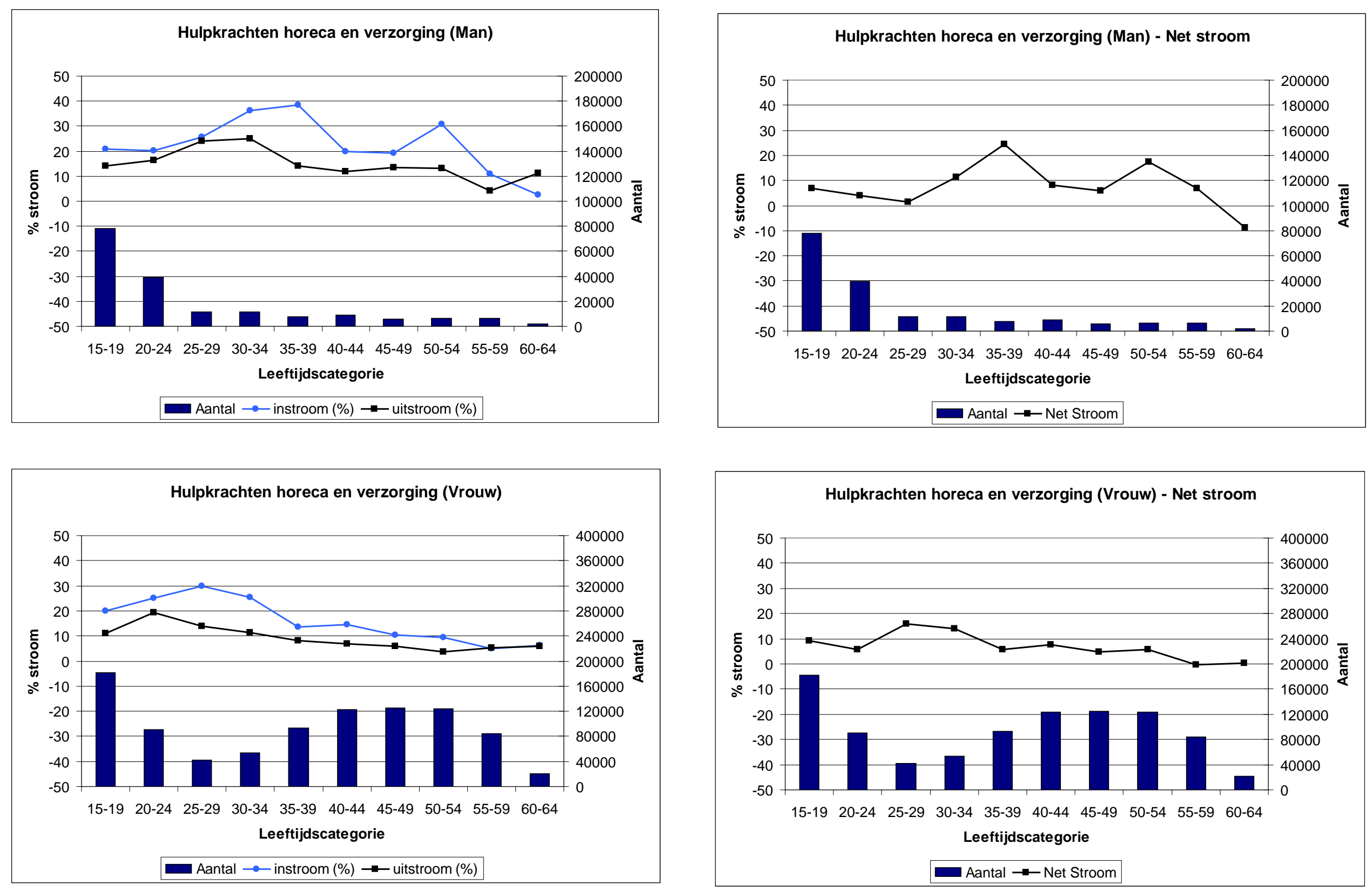

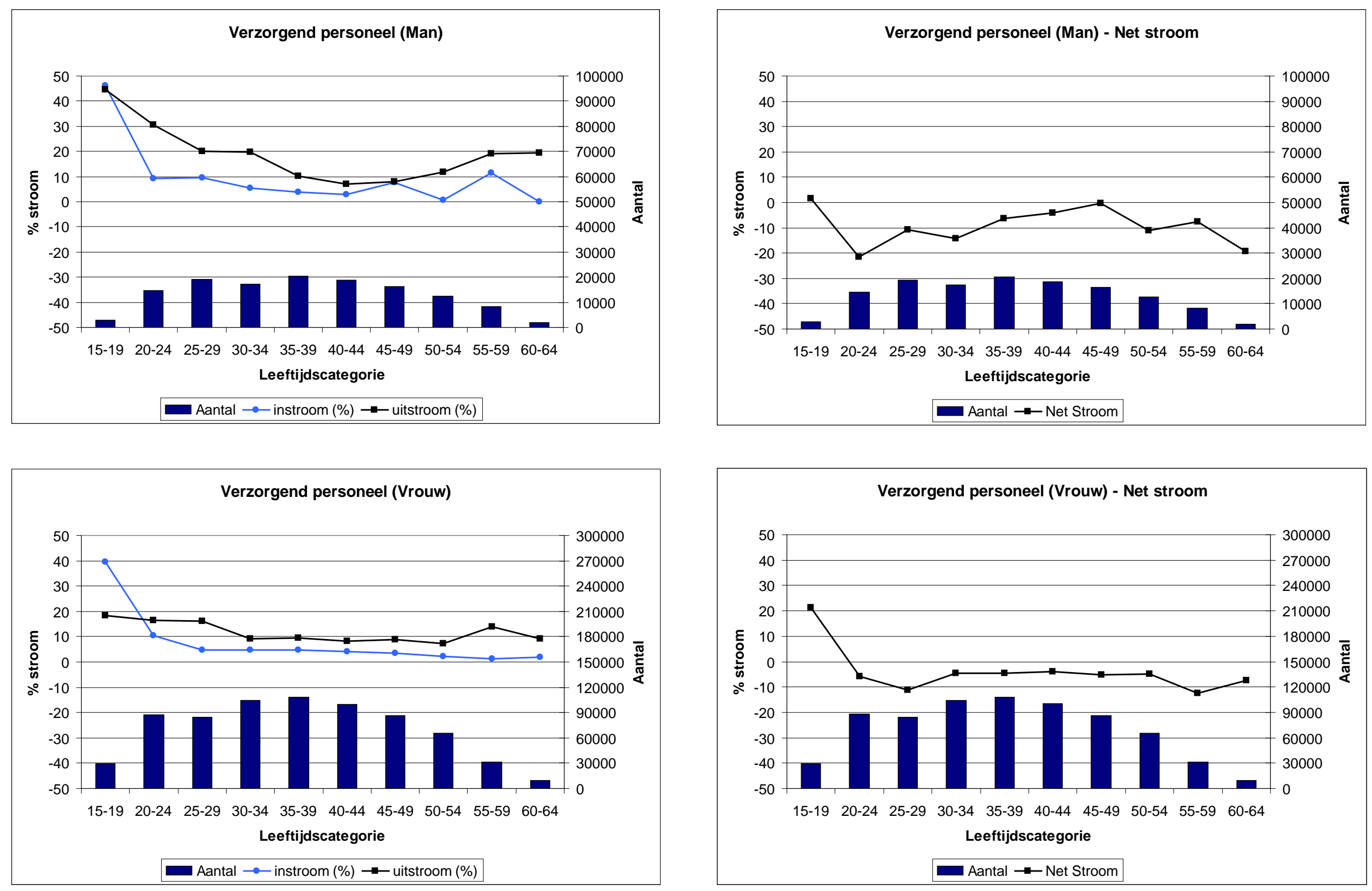